\title{
Six Strategies for Rehabilitating Land Disturbed by Oil Development in Arctic Alaska
}

\author{
M. TORRE JORGENSON ${ }^{1}$ and MICHAEL R. JOYCE ${ }^{2}$
}

(Received 13 October 1993; accepted in revised form 31 August 1994)

\begin{abstract}
Oil development in arctic Alaska has left a range of disturbed lands that will eventually require rehabilitation. These lands include gravel roads and pads, gravel pits and overburden stockpiles, drilling reserve pits, occasional accidental spills, and other minor disturbances to the tundra. A long-term research program investigating site-specific and cost-effective methods for rehabilitating degraded lands for fish and wildlife habitat has developed six general strategies that are applicable to the range of disturbed conditions. These strategies include 1) flooding of gravel mine sites for fish habitat, 2) creation of wetlands in ponds perched on overburden stockpiles, 3) revegetation of thick gravel fill and overburden to compensate for lost wildlife habitat, 4) removal of gravel fill to help restore wet tundra habitats, 5) restoration of tundra on less severely modified habitats, and 6) remediation of areas contaminated by oil spills, seawater spills, and drilling mud. Although most techniques are in the early stage of evaluation, preliminary results suggest that successful methods are available to create diverse, productive, and self-sustaining communities that are useful to a range of wildlife.
\end{abstract}

Key words: Arctic, Alaska, disturbance, habitat, tundra, oilfield, rehabilitation, revegetation, restoration, wetlands

RÉSUMÉ. L'exploitation du pétrole dans la zone arctique de l'Alaska a entraîné une gamme de perturbations sur des terrains qu'il va falloir un jour réhabiliter. Ces derniers comprennent les routes et plates-formes de gravier, les gravières et déblais des terrains de recouvrement, les bassins de réserve de forage, les terrains ayant été le site de déversements accidentels occasionnels et autres perburbations mineures de la toundra. Six stratégies générales applicables à la gamme des terres ayant subi des perturbations ont été développées grâce à un programme de recherche à long terme portant sur les méthodes — rentables et spécifiques à chaque site — de réhabilitation des terres dégradées pour la faune aquatique et terrestre. Ces stratégies comprennent 1) l'inondation de gravières pour l'habitat du poisson, 2) la création de terres humides dans les étangs situés en haut des déblais des terrains de recouvrement, 3) la restauration de la végétation sur les remblais de gravier et déblais épais, pour compenser la perte de l'habitat faunique, 4) l'enlèvement des remblais de gravier comme aide à la restauration des habitats de toundra humide, 5) la restauration de la toundra dans des habitats n'ayant pas subi de modifications aussi sérieuses, et 6) la décontamination de zones ayant subi des déversements de pétrole, d'eau de mer et de boue de forage. Bien que la plupart des techniques en soient au stade préliminaire de l'évaluation, les premiers résultats donnent à penser qu'il existe des moyens efficaces de créer des communautés diverses, productives et autorégulatrices qui permettent la présence d'une flore et d'une faune diversifiées.

Mots clés: Arctic, Alaska, perturbation, habitat, toundra, gisement pétrolier, réhabilitation, revégétation, restauration, terres humides

Traduit pour la revue Arctic par Nésida Loyer.

Нефтяныс разработки в арктической зове Аляски оставили после себя различные типы потревоженных ландтафтов с нарушеняем почвенного слоя, которые рано или поздно придётся восстанявивать. Сюда относятся: Дороги с гравийным покрытием и насыпи, гравийные карьеры и грунтовые отвалы, амбарные ямы для бурового раствора, нефтяные иятна и другие повреждения тундрового покрова.

В результате иродолжительных исследовалий, направленных на выявление спедиализированных и эффективных методов восстановления пострадавишх участков до состояния, пригодного для обятання рыб, диких жнвотвых в гтид, было разработано шесть генера.ьных стратегий, применительно к различным тишам нарушенных ландшафгов. Эти стратегии включают: (1) Затопление гравийных карьеров в целях создания среды обитания рыб. (2) Создание болот в водоёмах на грунтовых отвалах. (3) Восствновление растительного похрова поверх гравийной засышки и отвалов пустой породы для комненсации потеря вой среды обитапия. (4) Уборка засншки дыя восстановления заболоченных участков. (5) Восстановление слабо повреждённых участков. (6) Восставовление участков, поражённых разливами нефти, бурового раствора, а также морской воды.

Несмотря на то, что эффективность большинства методик восстановления ешё не оценена нами до конда, предварительные результаты дают возможность предположить наличве эффективных способов созданиz разнообразвой, продуктиввой и устойчивой среды обитания для целого ряда диких животных в птиц.

Ключевые слова: Арктическая зона, Аляска, нарушение, среда обитания, тундра, вефтяные разработки, восстановленде, восстановление растительного покрова, зяболоченняя тунца.

${ }^{1}$ Alaska Biological Research, Inc., P.O. Box 81934, Fairbanks, Alaska 99708, U.S.A.

${ }^{2}$ ARCO Alaska, Inc., P.O. Box 100360, Anchorage, Alaska 99510, U.S.A.

(C) The Arctic Institute of North America 


\section{INTRODUCTION}

Development of land resources in the Arctic has been increasing steadily as a result of oil exploration and development, coal and mineral development, military activity, and expanding Native communities. In northern Alaska, oil exploration has been occurring since the late 1940s, numerous military facilities have been constructed and abandoned since the 1950s, and full-scale oil development in the Prudhoe Bay region has been ongoing since 1973. Rehabilitation of land that has been disturbed by these activities presents special challenges because of the harsh environment and the importance to fish and wildlife of tundra habitats on the North Slope. Therefore, improvement of the diversity, productivity, and sustainability of degraded lands must occur within the severe constraints posed by arctic conditions and must create habitats that are useful to fish and wildlife.

To address this need, we have been conducting a long-term program for developing appropriate, cost-effective methods for rehabilitating the wide variety of sites affected by oil development (Joyce and Jorgenson, 1991). Such a commitment is necessary because evaluation of the response of terrestrial and aquatic communities to new site preparation, plant cultivation, and fish and wildlife enhancement techniques is a lengthy process in the Arctic, where summers are short and growth rates are slow. It is only over a long time scale that the success of rehabilitation techniques can be evaluated for long-term productivity and stability rather than for short-term responses.

We have identified fish and wildlife habitat as the primary eventual use of rehabilitated lands because of the abundance and diversity of wildlife found on the Arctic Coastal Plain. The importance of the varied habitats of this area to fish and wildlife requires that rehabilitation efforts be attentive to habitat requirements of a wide variety of species, rather than just stabilizing the surface or covering the surface with some type of vegetation. Developing rehabilitation strategies to create fish and wildlife habitats is a challenge, however, in a region where habitat requirements of most fish and wildlife species are insufficiently understood and rehabilitation technology has not been developed adequately.

Our research has benefited from a growing body of information regarding arctic rehabilitation. Studies of the patterns of disturbance (Lawson et al., 1978; Walker and Everett, 1987; Walker and Walker, 1991) and natural revegetation (Chapin and Shaver, 1981; Abele et al., 1984; Everett et al., 1985; Gartner et al., 1986; Cargill and Chapin, 1987; Ebersole, 1987; Kershaw and Kershaw, 1987; McKendrick, 1987; Walker et al., 1987; Felix and Raynolds, 1989) have contributed to our knowledge of rates of ecosystem recovery. Similarly, advantages and limitations of various revegetation techniques have been determined by numerous investigators (Klebesadel, 1971; Mitchell, 1979; NativePlants, 1980; Johnson, 1981; McKendrick, 1986; Younkin and Martens, 1987; Wright, 1987; McKendrick, 1991; Densmore, 1992; Jorgenson et al., 1994). However, few attempts have been made to create habitats for specific wildlife species (Densmore et al., 1987) or to document use of rehabilitated lands by wildlife (Jorgenson, 1988a; Pollard et al., 1990; Troy, 1991; Winters, 1990). Future rehabilitation research may be stimulated by recommendations made for wetland restoration on the North
Slope by the U.S. Environmental Protection Agency (Wyant and Knapp, 1992).

In this review, we differentiate between revegetation, rehabilitation, and restoration efforts. Revegetation refers to the establishment of vegetation, regardless of composition, on a disturbed area. Rehabilitation is used as a broader term to denote the establishment of productive and functioning systems, and may include revegetation, erosion control, or fish transplanting efforts. Finally, restoration is used as a more restrictive term referring to the long-term process of reestablishing the original composition, structure, and function to a disturbed site.

Our objective in this paper is to organize the results of both our research and that of others into a comprehensive strategy for rehabilitating most types of degraded lands in the Arctic into diverse habitats useful to a wide range of fish and wildlife. While most of the work we review has been done on the Arctic Coastal Plain in Alaska, much of it is applicable to other regions in the Arctic.

\section{OIL DEVELOPMENT IN THE ARCTIC}

Since oil was first discovered at Prudhoe Bay in 1969, the development of oilfield facilities has expanded into seven separate fields, and exploration continues in all directions (Fig. 1). Currently, oil is being produced from the Prudhoe Bay, Kuparuk, Milne Point, Lisburne, Pt. McIntyre, Endicott, and Niakuk fields; the first two are the largest producers in the United States. In addition, numerous other oil reservoirs (e.g., West Sak, Ugnu, Colville Delta, Gwydyr Bay, Pt. Thompson, Mikkelson Bay) are being evaluated for potential development (Francois and Gachter, 1992).

To prevent thawing of the underlying permafrost and to provide a stable surface for development, gravel fill is essential to the development of arctic oilfields and accounts for most of the land affected by oil development (Fig. 2). As of 1993, approximately 5675 ha of land in the seven oilfields (excluding offshore development) were affected directly by facility development, including 4193 ha of gravel roads and pads (excluding reserve pits), 943 ha at 20 gravel mine sites (includes pit, overburden stockpile, and access roads), and 539 ha at 373 reserve pits (BP Exploration (Alaska) Inc., unpubl. data). In the newer oilfields (Endicott, Pt. McIntyre, and Niakuk) reserve pits were not used. In addition to these direct impacts, indirect impacts, such as impoundments and thermokarst, cover more than twice the area covered by fill within the most heavily developed portion of the oilfield (Walker et al., 1987).

The construction of facilities has generated four general classes of soil materials: 1) gravel fill (generally $1.5 \mathrm{~m}$ thick), 2) overburden, 3) drilling muds and cuttings, and 4) tundra sod (Fig. 3). Gravel for roads, drilling pads, and facilities has been excavated from gravel deposits that occur throughout the area, either along barren floodplains or in glaciofluvial deposits that occur at depths below $8 \mathrm{~m}$. In the oilfields near Prudhoe Bay, where the floodplains of the Sagavanirktok and Kuparuk Rivers are more accessible, most of the gravel has been taken from floodplain deposits at or near the surface. In contrast, in Kuparuk 


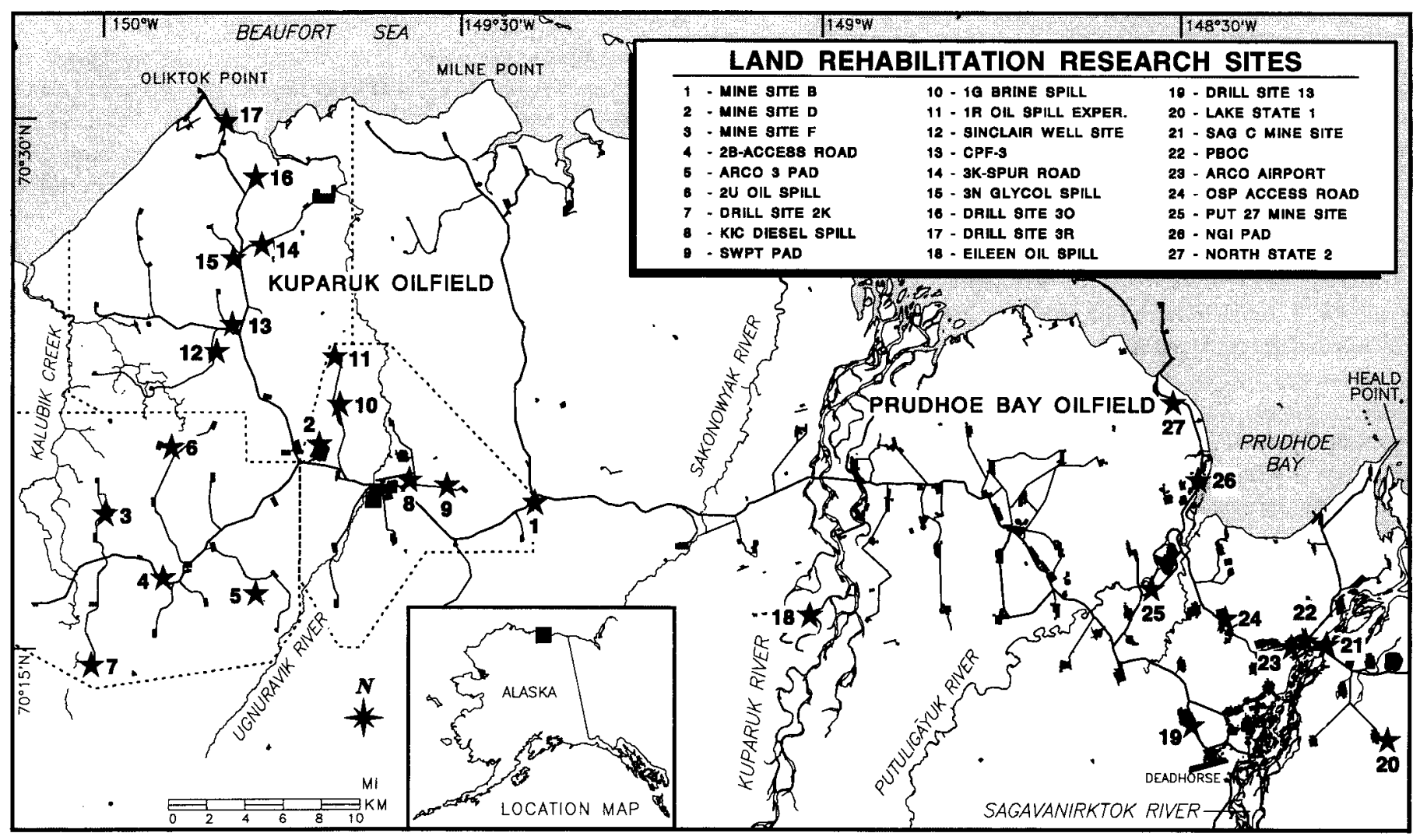

FIG. 1. Extent of development facilities in the Kuparuk and Prudhoe Bay Oilfields in 1991 and location of rehabilitation research sites.

most of the gravel has been taken from subsurface glaciofluvial deposits. These glaciofluvial deposits are overlain by a layer of silty, gravelly sands (generally $6-8 \mathrm{~m}$ thick) and are capped by a layer of organic-rich silts and peat (upper 0.5-2 m). During gravel extraction, the overlying materials were removed and set aside in overburden stockpiles. At the newest mine sites in the Kuparuk oilfield, the organic-rich silt was stockpiled separately for use in land rehabilitation and is referred to as "tundra sod." Since abandonment, most of the mine pits have become flooded.

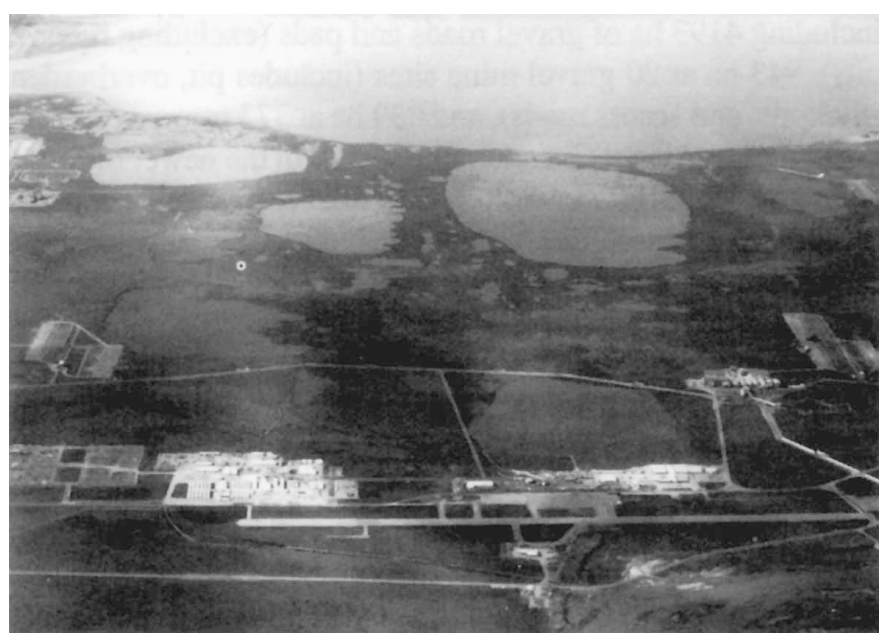

FIG. 2. Aerial view of oilfield facilities in Prudhoe Bay, Alaska, showing an airstrip (foreground), camp facilities (foreground), drill sites with reserve pits (far left and right), and central processing facilities (right).

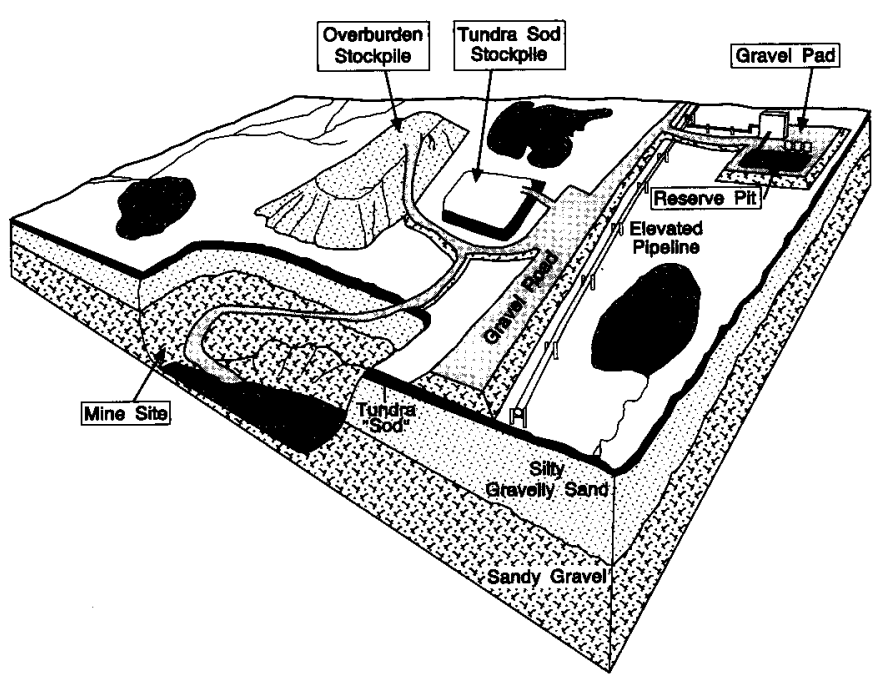

FIG. 3. Cross-sectional diagram depicting the five main types of disturbances (gravel mines, overburden stockpiles, gravel fill, drilling muds and cuttings in reserve pits, and small patches of tundra soil) that will require rehabilitation after oil development in arctic Alaska.

\section{CHALLENGES FOR ARCTIC REHABILITATION}

The Arctic poses many impediments to the rehabilitation of degraded lands: a short growing season, low temperatures, low precipitation, high winds, and a shortage of available nutrients (Billings, 1987; Chapin, 1987). Despite the severity of the environment, recent research has shown that arctic plants are 
remarkably well adapted to low temperatures and that it is primarily other factors (e.g., a short growing season, low nutrient availability due to slow decomposition, and restricted drainage and poor aeration caused by permafrost) that limit plant growth and reproduction (Chapin and Shaver, 1985; Chapin et al., 1992). Plants have responded to the short growing season by increasing vegetative reproduction over seed production (Billings, 1987). Nutrient availability is much lower than in temperate ecosystems because low temperatures strongly inhibit chemical weathering and biological decomposition and because permafrost makes much of the mineral soil inaccessible to plant roots (Chapin et al., 1992). Although such factors are serious constraints, knowledge of these factors is essential in developing techniques for manipulating the microclimate of the surface, reconstructing viable soil processes, and selecting plant species for their abilities to grow and reproduce.

Knowledge of the limitations imposed by arctic hydrology also provides a basis for formulating solutions. The arid environment results in low soil moisture on elevated surfaces and contributes to the salinization of disturbed terrain (Jorgenson, 1988a). Low soil moisture not only stresses plants directly but also reduces the availability of nutrients by reducing the movement of nutrients through the soil. Further, soil salinity can aggravate moisture stress in soils with low moisture content. In contrast, tundra soils generally remain saturated despite the low precipitation, because subsurface drainage is impeded by permafrost. The supra-permafrost groundwater can therefore be a potential source for water, which can reach plants via capillary rise through gravel fill. An understanding of the water balance at the soil surface and how the movement of groundwater affects the availability of nutrients can aid in developing techniques for improving soil moisture and nutrient availability.

One of the most difficult constraints to work within, however, is the arctic climate. The land is dominated by winter for nine months of the year and is free of snow only for a brief summer. Air temperatures during the short (7-10 week) growing season are low, and frost or snowfall can occur at any time. On the Arctic Coastal Plain at Barrow, annual precipitation is generally 50 $250 \mathrm{~mm}$, but only a third of it falls during the growing season (Dingman et al., 1980). For example, over an eight-year period (1983-90) at Prudhoe Bay, summer/fall precipitation averaged $65 \mathrm{~mm}$, with most of the rain falling during late summer (Thoman, 1990). The rest falls as snow during the winter and forms a dense, windblown snow pack. During spring breakup, water from the snow melt runs off in 3 to 10 days, but little is retained by the soil, which has thawed only a few centimeters (Ryden, 1981).

Despite the numerous difficulties, land rehabilitation efforts can take advantage of the plant species that have adapted to exploiting the wide variety of disturbed habitats that have resulted from the dynamic processes of the coastal plain landscape, such as drained thaw lakes, floodplains, sand dunes, coastal barrens, and frost boils (Bergman et al., 1977; Walker et al., 1980; Walker and Avecedo, 1987). Numerous species have adapted to colonizing these newly available substrates (Bliss and Cantlon, 1957; Peterson and Billings, 1980; Walker et al., 1980). Many of the species found colonizing natural disturbances also are found colonizing anthropogenic disturbances (Everett et al., 1985; McKendrick, 1987; Jorgenson et al., 1990).

Finally, the abundance and diversity of fish and wildlife found in the region provide both an imperative to conserve habitats and a challenge to create on degraded lands habitats that provide appropriate resources. The oilfields were built within a portion of the calving ground of Central Arctic Herd caribou (Rangifer tarandus), which numbered approximately 23500 animals in 1993 (R.D. Cameron, Alaska Dept. of Fish and Game, pers. comm., 1993). The area also provides important nesting and brood-rearing habitat for many species of waterfowl and shorebirds (Bergman et al., 1977; Troy, 1985; Meehan, 1986). Large lakes and rivers in the area provide important overwintering habitat for anadromous fish (Schmidt et al., 1989). Concern for both fish and wildlife and their habitats within the oilfield has become a central focus of studies relating to oilfield disturbances and the rehabilitation of degraded lands.

\section{SIX REHABILITATION STRATEGIES}

We have identified six general strategies, incorporating a variety of land rehabilitation techniques, that are applicable to the range of disturbed conditions resulting from oil development in arctic Alaska (Table 1). These strategies include: 1) flooding of gravel mine sites for fish habitat, 2) creation of wetlands in ponds perched on overburden stockpiles, 3 ) revegetation of thick gravel fill and overburden to compensate for lost wildlife habitat, 4) removal of gravel fill to help restore wet tundra habitats, 5) restoration of tundra on less severely modified habitats, and 6) remediation of areas contaminated by oil spills, seawater spills, and drilling mud. These strategies are intended to create habitats that are useful to a diversity of plants, invertebrates, birds, and mammals. The general goals of each strategy, as well as results of experiments evaluating various techniques applicable to each strategy, are reviewed below.

\section{Flooding of Gravel Mine Pits}

The availability of suitable overwintering habitat for fishes is a critical factor limiting fish populations in the central North Slope (Bendock, 1977). Most tundra lakes and streams cannot sustain winter populations because they freeze to the bottom; consequently, most overwintering fishes are confined to a few deep lakes, springs, and river pools that maintain sufficient quantities of water underneath the ice (Schmidt et al., 1989). Abandoned mine sites that are flooded with water and connected to nearby drainages potentially can support populations of overwintering fishes by providing a critical habitat resource (Hemming, 1989, 1992).

Early concerns over the effect of gravel removal on floodplain habitats prompted the U.S. Fish and Wildlife Service to fund a five-year study of potential impacts in arctic and subarctic environments (Joyce et al., 1980). To help mitigate the impacts of gravel removal, the Alaska Department of Fish and Game, with oil industry support, has been conducting long-term research designed to monitor water quality in flooded mine sites, 
TABLE 1. Six strategies for rehabilitating lands disturbed by oil development in arctic Alaska.

\begin{tabular}{|c|c|c|c|}
\hline Disturbance & Strategy & Examples of Techniques & Key Taxa (scientific names cited in text) \\
\hline Mine Pits & Flood to create fish habitat & $\begin{array}{l}\text { Creation of connecting channels to } \\
\text { streams } \\
\text { Excavation of littoral zone } \\
\text { Transplanting fish }\end{array}$ & $\begin{array}{l}\text { Fish: arctic cisco, broad whitefish, round whitefish, least } \\
\text { cisco, burbot, ninespine stickleback, Dolly Varden char, } \\
\text { arctic grayling, slimy sculpin, and fourhorn sculpin }\end{array}$ \\
\hline \multirow[t]{2}{*}{ Overburden stockpile } & Create wetlands in perched ponds & $\begin{array}{l}\text { Creation of berms and basins } \\
\text { Transplanting of aquatic graminoids } \\
\text { Transplanting of aquatic invertebrates }\end{array}$ & $\begin{array}{l}\text { Plants: pendent grass, tall cottongrass, water sedge, } \\
\text { Dupontia } \\
\text { Aquatic invertebrates: physid snails, aquatic worms, } \\
\text { seed shrimp, non-biting midges, water fleas, copepods } \\
\text { Birds: Canada goose, greater white-fronted goose, } \\
\text { northern pintails, Pacific loon, semipalmated sandpiper, } \\
\text { dunlin, and red-necked phalarope }\end{array}$ \\
\hline & Same as for gravel & See techniques listed below for gravel & See taxa listed below for gravel \\
\hline \multirow[t]{2}{*}{ Gravel Roads and Pads } & $\begin{array}{l}\text { Revegetate to compensate for lost } \\
\text { habitat }\end{array}$ & $\begin{array}{l}\text { Creation of berms and basins } \\
\text { Topsoil application } \\
\text { Sludge application } \\
\text { Fertilization } \\
\text { Seeding of native grasses } \\
\text { Seeding with native legumes and other } \\
\quad \text { forbs } \\
\text { Transplanting willows }\end{array}$ & $\begin{array}{l}\text { Plants: Tundra Bluegrass, Arctared Fescue, Alyeska } \\
\text { Polargrass, Norcoast Hairgrass, arctic alkaligrass, arctic } \\
\text { wormwood, alpine milkvetch, deflexed oxytrope, viscid } \\
\text { oxytrope, northern sweet-vetch, feltleaf willow, } \\
\text { roundleaf willow } \\
\text { Birds: Canada goose, greater white-fronted goose, } \\
\text { Lapland longspur, and snow bunting } \\
\text { Mammals: caribou }\end{array}$ \\
\hline & $\begin{array}{l}\text { Remove gravel to promote } \\
\text { wetland restoration }\end{array}$ & $\begin{array}{l}\text { Remove gravel } \\
\text { Create basins } \\
\text { Fertilization to promote natural } \\
\text { colonization } \\
\text { Seed with native grasses } \\
\text { Transplant sod and sprigs } \\
\text { Transplant willow cuttings }\end{array}$ & $\begin{array}{l}\text { Plants: pendent grass, tall cottongrass, water sedge, } \\
\text { Dupontia, Tundra Bluegrass, Arctared Fescue, Alyeska } \\
\text { Polargrass, Norcoast Hairgrass, arctic willow } \\
\text { Aquatic invertebrates: physid snails, aquatic worms, } \\
\text { seed shrimp, non-biting midges, water fleas, copepods } \\
\text { Birds: Canada goose, greater white-fronted goose, } \\
\text { northern pintails, Pacific loon, pectoral sandpiper, } \\
\text { semipalmated sandpiper, American golden-plover, } \\
\text { dunlin, red-necked phalarope }\end{array}$ \\
\hline Minor Disturbances & Promote natural recovery & $\begin{array}{l}\text { Leave as is } \\
\text { Reestablish natural drainage } \\
\text { Fertilization }\end{array}$ & $\begin{array}{l}\text { Reestablishment of original communities of plants, } \\
\text { invertebrates, birds, and mammals }\end{array}$ \\
\hline Contaminants & $\begin{array}{l}\text { Remediate to acceptable } \\
\text { contaminant levels }\end{array}$ & $\begin{array}{l}\text { Excavation and thermal treatment } \\
\text { Soil washing } \\
\text { Passive bioremediation } \\
\text { Landfarming } \\
\text { Bioventing, Air sparging }\end{array}$ & not applicable \\
\hline
\end{tabular}

monitor fish populations that have immigrated into flooded mine sites, introduce fishes into isolated sites, investigate ecological requirements of fishes, and test rehabilitation techniques to improve water quality. As a result of their work and recommendations to industry, five mine sites have been, or are in the process of being, rehabilitated for fish habitat.

Natural colonization by fishes has been rapid in mine sites that have been flooded and connected to adjacent streams with access channels (Hemming et al., 1989; Hemming, 1992). Flooded mine sites that are connected to large rivers (e.g., Sag Site C, Put 27, Kuparuk Deadarm) tend to have greater fish diversity than do those that are connected to small streams. Eleven species have been found at the three sites: arctic cisco (Coregonus autumnalis), broad whitefish (Coregonusnasus), round whitefish(Prosopium cylindraceum), least cisco (Coregonus sardinella), burbot (Lota lota), ninespine stickleback (Pungitius pungitius), rainbow smelt (Osmerus mordax), Dolly Varden char (Salvelinus malma), arctic grayling (Thymallus arcticus), slimy sculpin (Cottus cognatus), and fourhorn sculpin (Myoxocephalus quadricornis).
In contrast, flooded sites that are connected to small tundra streams (e.g., Mine Sites B and D) have been colonized by few species: broad whitefish, least cisco, and ninespine stickleback. At two sites, Mine Sites B and D, grayling have been introduced to provide recreational fishing opportunities. Several factors have contributed to differences in rates of colonization of the flooded mine sites. The presence of littoral habitat along the shoreline of the sites can contribute to higher algal production and greater abundance of zooplankton than in the deeper water in the middle of the pits (Hemming et al., 1989). In turn, the littoral habitat appears to be used more by juvenile fishes. Permanent connection of a mine site to a river allows colonization by fish and allows mine-dwelling fish to use the river for rearing and spawning. Other factors that could be implemented to enhance use by fish and wildlife include planting emergent vegetation in littoral zones, deposition of appropriate soil materials with plant propagules, increasing shoreline length and complexity, and creating islands for nesting waterfowl (Hemming, 1990).

Because of the importance of shallow littoral zones to pri- 
mary producers and fishes, shallow zones have been excavated at several former mine sites (e.g., Sag Site C and Mine Site D). Although the littoral zones of these sites have not been planted, relevant research has been conducted to develop techniques for reestablishing wetland vegetation, particularly the emergent aquatic grass Arctophila fulva. Studies by McKendrick (1991) and Moore (1991) have shown that the grass can be transplanted successfully, but that more information is needed on the rates of spreading after transplanting and on techniques for stimulating further growth.

\section{Perched Ponds on Overburden Stockpiles}

The creation of freshwater wetlands on overburden stockpiles has potential for providing high-value habitat for shorebirds and waterfowl and increasing habitat diversity on areas that compose a major portion of the disturbed land in the oilfields. Water bodies, particularly those with emergent vegetation, have been shown to be important habitat for many birds on the Arctic Coastal Plain (Bergman et al., 1977; Troy, 1985; Meehan and Jennings, 1988). Increasing the diversity of habitat patches on large overburden stockpiles is valuable because it emulates the patchiness of the adjacent tundra and provides habitat for a wide variety of wildlife.

In 1990, an experiment initiated at Mine Site D (Fig. 4) in the Kuparuk Oilfield took advantage of unique arctic conditions to manipulate the hydrology of dry overburden stockpiles (Jorgenson et al., 1992; Jacobs et al., 1993). Because of the presence of permafrost, impoundment of water on the gravelly sand appeared feasible (Jorgenson, 1989). Snow fences have been widely used in the Arctic to capture drifting snow for augmenting rural water supplies (Slaughter et al., 1975), building snow and ice roads (Johnson, 1981), and preventing snow accumulation around oilfield facilities. Instead of temporary snow fences, however, a large (3-4 $\mathrm{m}$ high) earthen berm was constructed on the overburden stockpile at Mine Site D, because it provided an inexpensive, permanent structure that required no maintenance.

Although the berm has been inefficient at capturing snow, it has been successful at increasing the input of meltwater to an adjacent impoundment (Fig. 5). In 1992, the berm accumulated $3050 \mathrm{~m}^{3}$ of water, which provided $84 \%$ of the meltwater recharge of the basin (Jacobs et al., 1993). Since its construction, the pond has increased in area from 0.2 ha in 1990 to 1.1 ha in 1992. In $1992,42 \%$ of the meltwater input was lost to evaporation over the summer.

The successful creation of perched ponds on previously dry, barren overburden has provided an opportunity to create a productive and diverse aquatic ecosystem. Although much information on the composition, structure, and function of natural aquatic ecosystems in the Arctic is available, additional research is required to better understand how to create a diverse community of emergent vascular plants, benthic invertebrates, phytoplankton, zooplankton, and bacteria in the Arctic (e.g., Bergman et al., 1977; Hobbie, 1984). Several techniques for creating aquatic ecosystems currently are being evaluated at Mine Site D. These include transplanting of aquatic grasses to increase overall primary productivity and provide vertical struc- ture (Fig. 6), and inoculating the pond with natural pond water and sediments to provide a medium for introducing aquatic bacteria, algae, and invertebrates. Nutrients were added to the pond from runoff from the surrounding overburden, which was fertilized and seeded with native grasses.

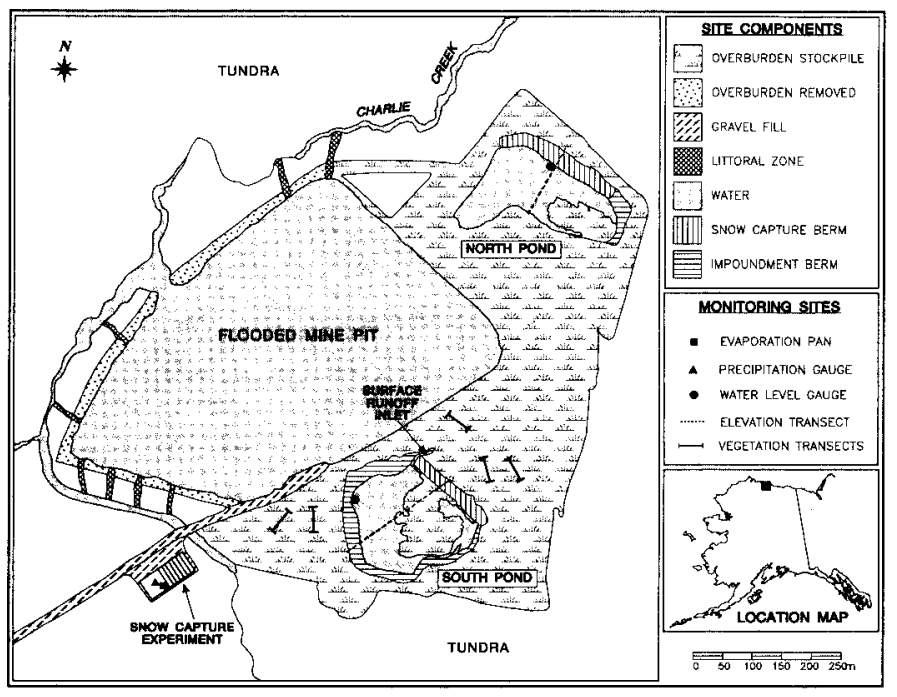

FIG. 4. Layout of rehabilitation efforts at Mine Site D in the Kuparuk Oilfield, Alaska, which included flooding the mine pit, excavation of channels to provide a littoral zone, revegetation of the large overburden stockpile, and creation of perched ponds on the overburden stockpile.

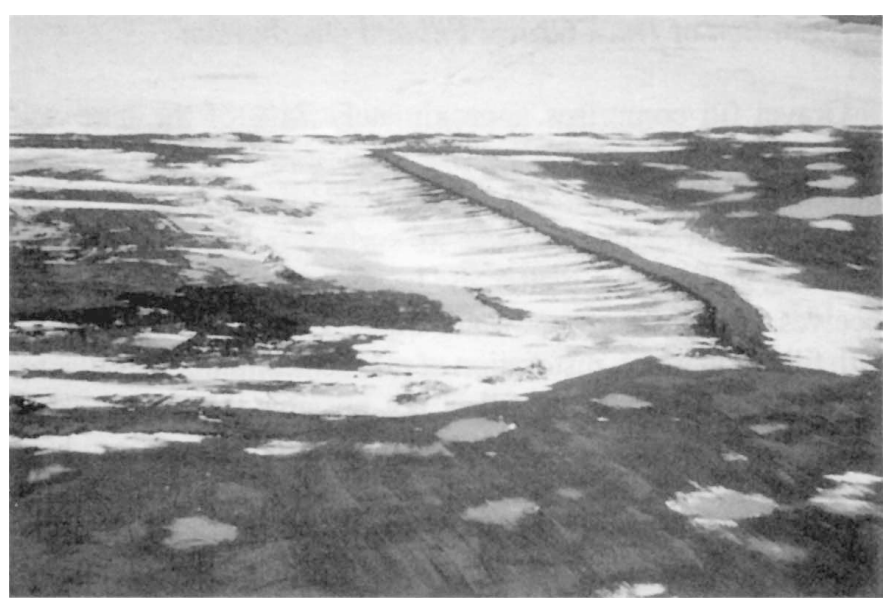

FIG. 5. Aerial view of a large berm that was used to capture drifting snow to increase meltwater input into impoundments at Mine Site D, Kuparuk Oilfield, Alaska.

After two years, growth of the emergent pendent grass (Arctophila fulva) in this pond has been robust, with mean stem density increasing from $3 \mathrm{stems} \cdot \mathrm{m}^{-2}$ to $12 \mathrm{stems} \cdot \mathrm{m}^{-2}$ in 1 year (Jacobs et al., 1993). Seedlings of the hydrophilic grass Dupontia (Dupontia fisheri) were found along the shoreline in 1993 after seeding in 1991. Similarly, phytoplankton production has been relatively high $\left(0.38 \mathrm{mg} \cdot \mathrm{L}^{-1}\right)$. However, the more complex development of an invertebrate community has been slower. In 1991, 24 taxa of invertebrates were introduced, but only nonbiting midges (Chironomidae) were present 6 weeks later. In 1992, two additional taxa, aquatic oligochaetes (Naididae) and 
dance flies (Empididae), were found. In 1993, water fleas (Daphnia spp.), copepods (Copepoda), and seed shrimp (Ostracoda) were found and some of their population densities were high. Even at this initial stage of development, the site has been used by numerous birds, including greater white-fronted geese (Anser albifrons), Pacific loons (Gavia pacifica), tundra swans (Cygnus columbianus), northern pintails (Anas acuta), semipalmated sandpipers (Calidris pusilla), dunlins (C. alpina), and red-necked phalaropes (Phalaropus lobatus).

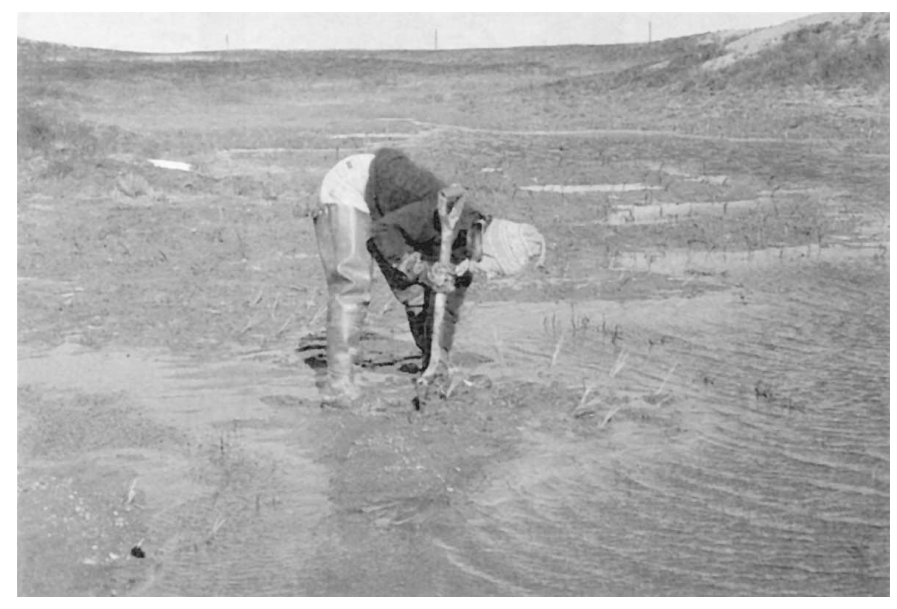

FIG. 6. View of transplanting emergent pendent grass in the perched pond at Mine Site D. Growth of seeded grass cultivars on the overburden is visible in the background.

\section{Revegetation of Thick Gravel Fill and Overburden}

Gravel fill comprises approximately $74 \%$ of the land degraded by oil development (BP Exploration (Alaska) Inc., unpubl. data). Unfortunately, thick gravel fill is the most difficult material to revegetate because its surface is low in moisture, nutrients, and organic matter and because the surface of the fill receives very little groundwater input. Consequently, at sites with fill left in place, restoration of plant communities similar to those buried beneath the fill is not possible. However, with sufficient site preparation and plant cultivation, simple, productive, and self-sustaining plant communities that are useful to a range of wildlife species can be established.

Natural colonization of thick gravel fill by plants is virtually absent even after 20 years because of poor soil properties (Jorgenson et al., 1990). Although fertilization can stimulate the germination of dormant seeds that have become embedded in the gravel's surface, the resulting increase in cover remains small and the added nutrients eventually leach away. At Lake State 1 Exploratory Well Site (Jorgenson et al., 1990), ARCO 3 Exploratory Well Site (Jorgenson, 1988b), and Mine Site D (Jorgenson and Cater, 1992), plant growth on fertilized plots remained negligible years after fertilization, and nitrogen levels dropped to original levels within a few years (Table 2).

In contrast, adding seeds of native grass cultivars at the same time as fertilization can result in the rapid development of plant cover (Table 2). At Mine Site D, a mean vascular plant cover of $40 \%$ was achieved during the third year after seeding and after being fertilized during the first and third seasons (Jorgenson and
Cater, 1992). At a less successful pad at Lake State 1, mean vascular plant cover was 6\% in 1989 (Jorgenson et al., 1990) after three seasons and increased slightly to $10 \%$ in 1991 . Although differences in grass growth among sites is not well understood, undoubtedly differences in soil properties, amount of fertilization, presence of contaminants, timing of seeding, density of seed application, seed quality, grazing, and weather are important factors.

Although productivity on thick gravel fill clearly will decline within a few years when seeding is accompanied by only one fertilization, uncertainty exists about how long nutrients will persist after multiple fertilizations and whether the multiple application of nutrients is a useful approach for developing selfsustaining communities. After a plant cover and root system have become established, the vegetation should be able to capture and recycle nutrients from subsequent fertilizations more efficiently. Five years after plots were seeded at Lake State 1 , mean vascular plant cover was $42 \%$ in a plot that was fertilized twice, in comparison to $10 \%$ for a plot that was fertilized once (Kidd and Jorgenson, 1992)(Table 2). The persistence of the effects of the second fertilization remains to be seen.

Although seeded grasses create a community with low diversity, they facilitate soil development and enhance the moisture regime. Substantial amounts of organic carbon are added to the soil by the dense root network of seeded grasses. In addition, above-ground plant parts increase soil moisture by capturing drifting snow, and the added organic material from decaying root mass may help increase retention of meltwater. On a flat gravel pad at Mine Site D, $10-15 \mathrm{~cm}$ of snow accumulated in areas seeded with grasses, whereas bare areas had no snow accumulation (Jorgenson and Cater, 1991). Input from meltwater was nearly as much as the $65 \mathrm{~mm}$ of precipitation that normally occurs over the course of a summer. The effect of below-ground carbon accumulation on moisture retention needs examination.

Whether seeded grasses facilitate or inhibit the natural colonization of other plant species on thick gravel fill is debatable. Numerous studies have shown that seeded grasses alter the patterns and rates of colonization of indigenous plants (Native Plants, 1980; Densmore et al., 1987; Densmore, 1992; McKendrick et al., 1993). However, these studies were done on areas where soil resources were adequate for plant growth. In contrast, the deterrence of colonization by indigenous plants is of little consequence on thick gravel pads, because so little natural colonization occurs. Thus, the only current option is to seed those species that are available. The challenge ahead, then, is to broaden the variety of native species that are available for seeding.

Several studies have investigated a wide range of plant species for revegetating gravel pads. The Alaska Plant Materials Center (APMC) has evaluated 52 varieties of native and nonnative plants (mostly grasses) for their ability to grow on gravel pads (Wright, 1987). The APMC also is currently investigating seven legume species that have potential for growing on gravel and providing a source of nitrogen through nitrogen fixation. These include alpine milkvetch (Astragalus alpinus), alpine sweet-vetch (Hedysarum alpinum), northern sweet-vetch (H. mackenzii), boreal oxytrope (Oxytropis borealis), deflexed oxytrope (O. deflexa), field oxytrope (O. campestris), and viscid 
TABLE 2. Techniques used for rehabilitating gravel fill, overburden, and minor tundra disturbances at selected sites in the Prudhoe Bay and Kuparuk Oilfields, northern Alaska.

\begin{tabular}{|c|c|c|c|c|c|c|c|c|c|}
\hline Disturbance & $\begin{array}{l}\text { Site } \\
\text { Manipulation }\end{array}$ & $\begin{array}{l}\text { Surface } \\
\text { Preparation }\end{array}$ & $\begin{array}{l}\text { Soil } \\
\text { Conditioning }\end{array}$ & Fertilization & $\begin{array}{l}\text { Planting } \\
\text { Technique }\end{array}$ & Site & $\begin{array}{l}\text { Years } \\
\text { Treatment }\end{array}$ & $\begin{array}{l}\text { Mean Vascular } \\
\text { Plant Cover } \\
(\% \pm \text { SD })\end{array}$ & Reference \\
\hline \multirow{27}{*}{$\begin{array}{l}\text { Gravel Fill } \\
(<1 \mathrm{~m} \text { thick }) \\
\text { Gravel Fill } \\
(>1 \mathrm{~m} \text { thick })\end{array}$} & \multirow[t]{2}{*}{ None } & \multirow[t]{2}{*}{ None } & \multirow[t]{2}{*}{ None } & None & Natural colon. & Sinclair & 23 & $41 \pm 4$ & Cater and Jorgenson (1993) \\
\hline & & & & Once & Natural colon. & Lake State 1 & 20 & $33 \pm 10$ & Jorgenson et al. (1990) \\
\hline & \multirow[t]{9}{*}{ None } & \multirow[t]{8}{*}{ None } & \multirow[t]{6}{*}{ None } & None & Natural colon. & ARCO 3 & 11 & $<1$ & Jorgenson (1988a) \\
\hline & & & & \multirow[t]{3}{*}{ Once } & Natural colon. & Lake State 1 & 3 & $1 \pm 1$ & Jorgenson et al. (1990) \\
\hline & & & & & Seeded grasses & Lake State 1 & 5 & $10 \pm 7$ & Kidd and Jorgenson (1992) \\
\hline & & & & & Seeded grasses & Drill Site 13 & 2 & $13 \pm 9$ & Jorgenson et al. (1992) \\
\hline & & & & \multirow[t]{2}{*}{ Twice } & Seeded grasses & Mine Site D & 3 & $40 \pm 18$ & Jorgenson and Cater (1992) \\
\hline & & & & & Seeded grasses & Lake State 1 & 5 & $42 \pm 14$ & Kidd and Jorgenson (1992) \\
\hline & & & Topsoil & Once & Seeded grasses & Drill Site 13 & 2 & $11 \pm 8$ & Jorgenson et al. (1992) \\
\hline & & & Sludge & Once & Seeded grasses & Mine Site F & 1 & $<1$ & Cater and Jorgenson (1994) \\
\hline & & Mulching & None & Twice & Seeded grasses & Mine Site D & 3 & $63 \pm 11$ & Jorgenson and Cater (1992) \\
\hline & \multirow[t]{4}{*}{ Berms \& basins } & \multirow[t]{4}{*}{ None } & \multirow[t]{2}{*}{ None } & Once & Seeded grasses & Drill Site 13 & 2 & $17 \pm 12$ & Jorgenson et al. (1992) \\
\hline & & & & Twice & Seeded grasses & Mine Site D & 3 & $59 \pm 32$ & Jorgenson and Cater (1992) \\
\hline & & & \multirow[t]{2}{*}{ Topsoil } & Once & Seeded grasses & Drill Site 13 & 21 & $4 \pm 8$ & Jorgenson et al. (1992) \\
\hline & & & & Once & Seeded grasses & Mine Site D & 3 & $138 \pm 23$ & Jorgenson and Cater (1992) \\
\hline & \multirow[t]{10}{*}{ Fill removal } & \multirow[t]{9}{*}{ None } & \multirow[t]{9}{*}{ None } & \multirow[t]{2}{*}{ None } & Natural colon. & 3K Road & 7 & $7 \pm 3$ & Cater and Jorgenson (1993) \\
\hline & & & & & Natural colon. & Airport & 2 & 0 & Kidd and Jorgenson (1992) \\
\hline & & & & \multirow[t]{7}{*}{ Once } & Natural colon. & 3K Road & 7 & $16 \pm 9$ & Cater and Jorgenson (1993) \\
\hline & & & & & Natural colon. & Airport & 2 & $3 \pm 6$ & Kidd and Jorgenson (1992) \\
\hline & & & & & Seeded grass & Airport & 2 & $11 \pm 8$ & Kidd and Jorgenson (1992) \\
\hline & & & & & Seeded sedges & Airport & 2 & $2 \pm 3$ & Kidd and Jorgenson (1992) \\
\hline & & & & & Seeded sedges & PBOC & 2 & $9 \pm 7$ & Kidd and Jorgenson (1992) \\
\hline & & & & & Sod plugs & Airport & 2 & $2 \pm 3$ & Kidd and Jorgenson (1992) \\
\hline & & & & & Sod plugs & PBOC & 2 & $27 \pm 17$ & Kidd and Jorgenson (1992) \\
\hline & & Scarifying & None & Once & Seeded grasses & N. State 2 & 1 & $3 \pm 1$ & Kidd et al. (1994) \\
\hline & \multirow{2}{*}{$\begin{array}{l}\text { Fill removal } \\
\text { and basins }\end{array}$} & \multirow{2}{*}{ None } & \multirow{2}{*}{ None } & \multirow[t]{2}{*}{ Once } & Sod plugs & N. State 2 & 1 & $1 \pm 1$ & Kidd et al. (1994) \\
\hline & & & & & Sprigging & N. State 2 & 1 & $1 \pm 1$ & Kidd et al. (1994) \\
\hline \multirow[t]{5}{*}{ Overburden } & \multirow[t]{4}{*}{ None } & \multirow[t]{3}{*}{ None } & \multirow[t]{3}{*}{ None } & None & Natural colon. & Mine Site B & 12 & $28 \pm 25$ & Jorgenson and Cater (1991) \\
\hline & & & & Twice & Seeded grasses & Mine Site B & 2 & $34 \pm 17$ & Jorgenson and Cater (1991) \\
\hline & & & & Once & Seeded grasses & Mine Site F & 4 & $47 \pm 11$ & Jorgenson and Cater (1992) \\
\hline & & Scarifying & None & Once & Seeded grasses & Mine Site D & 2 & 123 & Jacobs et al. (1993) \\
\hline & Berms \& basins & None & None & Once & Sprigging & Mine Site D & 2 & $<1$ & Jacobs et al. (1993) \\
\hline $\begin{array}{l}\text { Minor Tundra } \\
\text { Disturbance }\end{array}$ & None & None & None & None & Natural colon. & $2 \mathrm{~B}$ road & 8 & $22 \pm 23$ & Jorgenson and Cater (1991) \\
\hline
\end{tabular}

oxytrope (O. viscida) (Moore, 1993). Three other forbs, siberian aster (Aster sibiricus), arctic wormwood (Artemisia arctica), and dwarf fireweed (Epilobium latifolium), are being tested for commercial production because they are well adapted to dry, gravelly soils. McKendrick (1990) has initiated a 10-year study toevaluate 63 species of plants from nearby tundraandfloodplains for their potential to grow on gravel fill. Because collection or production of large amounts of seed is difficult, a limited amount of seed grown in nursery gardens could be used to introduce seed on gravel pads so plants that become established will serve as mother plants to continue the colonization (McKendrick, 1990). Presently, only four cultivars are commercially available for planting: Tundra Bluegrass (Poa glauca), Arctared Fescue (Festuca rubra), Alyeska Polargrass (Arctagrostis latifolia), and Norcoast Hairgrass (Deschampsia beeringensis). However, even the availability of these species is becoming increasingly sporadic because commercial growers have been unable to sustain production underfluctuating market conditions. Because the improvement of soil properties holds the key to successful revegetation, numerous site preparation techniques to improve soil moisture and nutrient availability on a long-term basis are being investigated. Techniques for modifying the hydrologic balance include the creation of small berms to capture drifting snow, addition of various soil amendments to increase water retention, and the addition of mulch to reduce evaporation. Techniques for increasing nutrient availability include the application of organic topsoil and sewage sludge and the use of nitrogen-fixing legumes.

Manipulation of the hydrologic balance of gravel pads has been evaluated by using small berms ( $50 \mathrm{~cm}$ high) at Mine Site $\mathrm{D}$ (Jorgenson and Cater, 1991) and large berms (1 mhigh) at Drill Site 13 (Jorgenson et al., 1992) to capture drifting snow for increasing the amount of available meltwater. At both sites, berms were effective at increasing soil moisture during early summer. The amount of water added far exceeded the storage capacity of the gravel, however, and most of the excess water was lost as throughflow. At Mine Site D, mean vascular plant cover after three years was significantly higher $(p<0.05)$ in the bermed plots that were seeded and fertilized $(59 \%)$ than in the control treatment (40\%)(Table 2). At Drill Site 13, mean vascular plant cover after two years was not significantly different $(p=0.21)$ between the berm treatment $(17 \%)$ and the control treatment $(13 \%)$.

Over the long term, any excess throughflow of water may leach nutrients from the soil's surface. To address this concern, an experiment was initiated at Mine Site F to evaluate the ability of organic topsoil, sandy overburden, and a starch-based polymer absorbent (Ag-Sorbent Flakes) to increase the moisture- 
holding capacity of gravel (Cater and Jorgenson, 1993). Initial results have found that soil water storage was almost twice as high in the organic and sandy overburden treatments and slightly higher in the polymer treatment than in the control gravel.

Reducing evaporation is another way to alter the water balance. Experimental application of straw mulch at Mine Site $D$ revealed that mulch actually increased evaporation, presumably because the mulch intercepted small amounts of precipitation during the summer, preventing it from entering the soil (Jorgenson and Cater, 1991). Although the mulch did not increase soil moisture, mean vascular plant cover $(63 \%)$ in the mulch treatment was significantly higher $(p<0.05)$ than in the unmulched treatment (40\%) after three growing seasons, probably because reduced desiccation at the soil surface aided germination (Table 2).

Of all site preparation treatments, the addition of organic topsoil improves soil moisture and nutrient availability the most (Jorgenson and Cater, 1991). At Mine Site D, topsoil addition increased soil water storage by 35 to $64 \%$ and greatly increased nutrient availability. Available nitrogen was five times higher in the topsoil treatment (135 ppm) than in the unamended gravel $(26 \mathrm{ppm})$ two years after fertilization. Even without fertilization, the amount of available nitrogen in a plot with organic topsoil remained high (81 ppm), presumably because of rapid mineralization of the organic matter. The application of topsoil within berms has provided the highest mean vascular plant cover $(138 \%)$ of any treatment combination, and there has been no indication of decreased growth over the three years that this site has been monitored (Fig. 7, Table 2). Unfortunately, the amount of organic topsoil that is available in the Kuparuk Oilfield, where efforts were made to conserve topsoil at the newest mine sites, is sufficient to cover only about $10 \%$ of the current roads and pads if a 5-cm thick layer is applied to the gravel.

Because of the limited supply of organic matter, the potential use of sewage sludge in the Kuparuk Oilfield was evaluated by examining sludge properties and regulatory requirements (Jorgenson and Cater, 1991). With regulatory approval, sludge was air dried during the summer in 1992 to reduce the level of pathogens and was applied in experimental test plots at Mine Site F to compare the effects of three rates of application (5, 9, and 18 $\mathrm{mt} \cdot \mathrm{ha}^{-1}$ ) and monitoreffects on waterquality (Cater and Jorgenson, 1993). After two summers, the plot with the highest application rate $\left(18 \mathrm{mt}^{-} \mathrm{ha}^{-1}\right)$ had levels that were similar to those in unamended gravel (control) of organic carbon ( $0.31 \mathrm{vs} 0.28 \%$ ), total nitrogen ( 0.03 vs $0.02 \%)$, exchangeable nitrogen ( $4 \mathrm{vs} 2 \mathrm{mg} / \mathrm{kg}$ ), and exchangeable phosphorus ( $9 \mathrm{vs} 3 \mathrm{mg} / \mathrm{kg}$ ). Although differences were pronounced immediately after application, soil properties did not appear to be improved substantially on a long-term basis at this relatively low application rate. Potentially, the sludge could be applied on 5-10\% of the gravel fill in the Kuparuk Oilfield if it is collected over a 20 -year period from camp facilities.

Finally, recognizing the limited amount of both organic topsoil and sludge, the use of legumes to increase the long-term availability of nitrogen through nitrogen fixation is being evaluated. Test plots were set up at Drill Site 13 in 1990 and at Mine Site F in 1992 to evaluate 10 species of indigenous legumes and other forbs (Astragalus alpinus, Hedysarum alpinum, $H$.

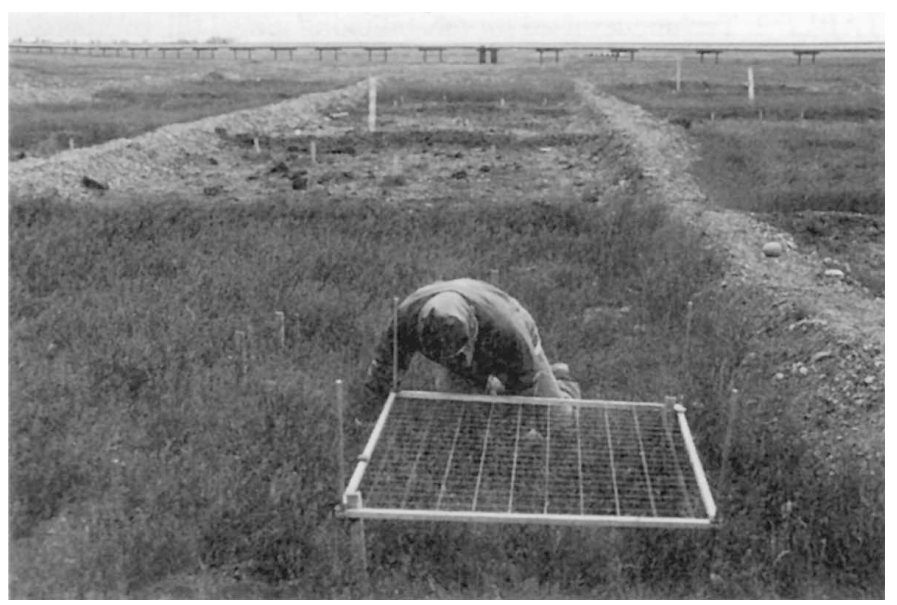

FIG. 7. View of experimental plots on a thick gravel pad near Mine Site D, where small berms were created to increase snowmelt and topsoil was applied to increase soil water storage and provide nutrients. Plant cultivation treatments include seeded native grass cultivars (foreground), tundra plugs and willow cuttings (middle), and natural colonization (bare plot in background).

mackenzii, Oxytropis borealis, O. campestris, O. deflexa, O. viscida, Aster sibiricus, Artemisia arctica, and Epilobium latifolium). In conjunction with these field trials, the APMC has planted test plots near Fairbanks to evaluate the potential for cultivating commercial quantities of seed (Moore, 1993). Although there are many outstanding questions about the technical and economic feasibility of using legumes, they provide one of the few potential solutions for increasing nitrogen availability on a long-term basis. Therefore, evaluation of the feasibility of using legumes is one of our highest priorities for future research.

Although a plant community similar to the original community that was buried cannot be created on thick gravel fill because the soil environments are too different, research has shown that productive and sustainable communities can be created. The new, simpler communities can compensate for lost habitat by providing a productive cover that is useful to grazing animals, such as caribou, geese, lemmings, and arctic ground squirrels (Spermophilusparryii), and seed foraging birds, such as Lapland longspur (Calcarius lapponicus) and snow buntings (Plectrophenax nivalis). For example, use of rehabilitated areas by geese, as indicated by mean scat density, was much higher at Lake State $1\left(1.4-6.7 \mathrm{scats} \cdot \mathrm{m}^{-2}\right)$ and Mine Site B $\left(10.7 \mathrm{scats} \cdot \mathrm{m}^{-2}\right)$ than in adjacent wet meadows $\left(<0.1 \mathrm{scats} \cdot \mathrm{m}^{-2}\right)($ Jorgenson et al., 1990; Jorgenson and Cater, 1991). Similarly, caribou frequently have been observed foraging at sites that have been seeded and fertilized, presumably because the plant tissue has higher nutrient concentrations.

\section{Wetland Restoration after Gravel Removal}

The removal of gravel fill has received increased emphasis recently (Post, 1990) as a means for restoring wetlands, because it reestablishes pedologic and hydrologic characteristics similar to those of the original state. Gravel thickness has been found to be the most important variable in determining rates of natural colonization and plant growth. In a survey of disturbed sites, Jorgenson et al. (1990) found that rates of plant growth and 
species diversity were much higher on thin $(<25 \mathrm{~cm}$ thick) gravel fill than on thick $(>80 \mathrm{~cm})$ gravel fill. The mean annual increment in plant cover (percent cover/years abandoned) was $1.76 \%$ \pm 0.94 SD on thin gravel but only $0.04 \% \pm 0.05$ SD on thick gravel. Similarly, germination of seeded grasses decreased exponentially with fill thickness (Jorgenson, 1988b). Further, maximal density of native grass seedlings was $<50 \mathrm{~m}^{-2}$ on fill $>1 \mathrm{~m}$ thick, but was $2150 \mathrm{~m}^{-2}$ on fill $<0.25 \mathrm{~m}$ thick. These differences were attributed to different rates of capillary rise of groundwater (Jorgenson, 1988b).

Because of the rapid movement of groundwater into thin gravel fill, not only is growth better than that on thick fill, but the diversity of naturally colonizing plants is greater. On the 17 thin pads surveyed, 64 species were found colonizing the gravel; growth typically was dominated by hydrophytic species found in the adjacent tundra and typically included water sedge (Carex aquatilis), tall cottongrass (Eriophorum angustifolium), and russet cottongrass (E. russeolum) (Jorgenson et al., 1990). In addition, the productivity and diversity of these sites were enhanced by the presence of polygonal troughs that are formed by the thermal degradation of ice-wedges (Fig. 8). In contrast, plant growth on the thick gravel pads was limited to a few scattered, xeric forbs, (e.g., Draba spp., Cochlearia officinalis, Braya purpurascens, Epilobium latifolium) and grasses (mainly Festuca baffinensis).

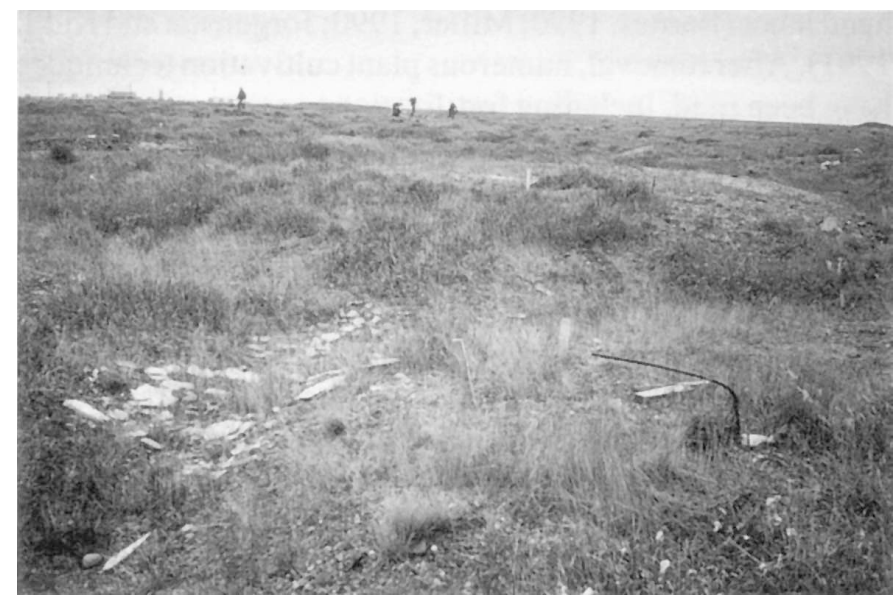

FIG. 8. View of plant growth on thin gravel pad at the Sinclair Exploratory Well Site in 1992, 23 years after it was abandoned, showing the formation of deep polygonal troughs that have resulted in a variety of microsites for natural plant colonization.

Several experiments have evaluated various plant cultivation techniques for restoring wetland vegetation on sites where gravel fill has been removed (Jorgenson, 1988a; Jorgenson and Kidd, 1991). These techniques include natural colonization, natural colonization assisted by fertilization, fertilization and seeding of native grass cultivars, fertilization and seeding of locally collected seed from hydrophytic sedges and grasses, and fertilization and transplantation of plugs from wet sedge meadows (Fig. 9). Preliminary results indicate that all of the fertilized treatments were performing well, including plots that were fertilized to assist natural colonization (Table 2).
The removal of gravel not only increases the number of species that can be planted successfully, but also provides the opportunity to create a diversity of habitats. At North Prudhoe Bay State 2 Exploratory Well Site, an experiment created a mosaic of moist-meadow, wet-meadow, and aquatic-marsh habitats by creating differing hydrologic regimes after removal of gravel and by planting appropriate species (Kidd et al., 1994). To create moist meadows, a thin layer (mean depth of $35 \mathrm{~cm}$ ) of gravel was left in place to provide a seedbed above the water table and the surface was fertilized and lightly seeded with native grass cultivars. The light seeding was done to promote a rapid sparse cover, yet allow space for natural colonization. For sedge marshes, two basins (mean depths of 20 and $33 \mathrm{~cm}$ below the original tundra grade) were excavated to allow shallow flooding during early summer. The shallow basins were planted with plugs obtained from adjacent wet meadows. Finally, two deeper ponds (mean depths of 20 and $47 \mathrm{~cm}$ ) were created and the margins were planted with the emergent pendent grass. After the first summer, survival of the transplants was high and prospects for continued growth looked promising.

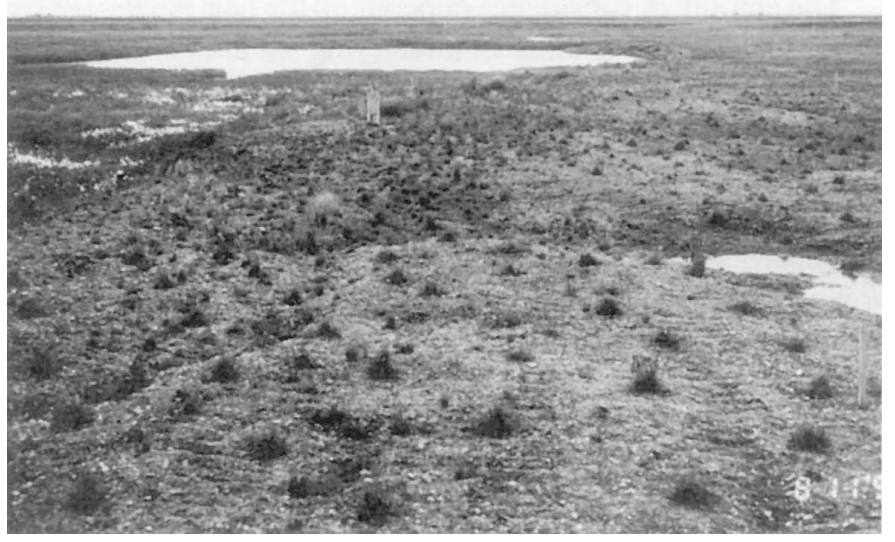

FIG. 9. View of plant growth after transplanting tundra plugs on a thin gravel pad near the Prudhoe Bay Operations Center, Alaska.

The analysis of natural colonization rates and experimental test plots on thin fill indicates that the restoration of diverse, productive, and self-sustaining wetland plant communities can be accomplished within a reasonable period of time, perhaps 10 to 30 years. Initial results suggest that fertilization alone is adequate to promote restoration of wetlands. Although a productive cover may take longer if you do not seed with native grasses, the naturally colonizing plants are better adapted for wet sites than grass cultivars and the resulting community is similar to naturally occurring wet meadows. While our initial work suggests that restoration of wet tundra appears feasible, it is unlikely that moist or dry tundra habitats can be restored to conditions similar to natural communities without much greater effort, if at all. Restoration of wet habitats appears feasible because the wet habitat is dominated by graminoids, has lower species diversity, and typically occurs as an early successional stage dominated by species that typically colonize naturally disturbed sites. In contrast, moist and dry tundra represent later 
successional stages that have higher species diversity and more complicated structure. In addition, moist and dry tundra are dominated by plants that have low growth rates and are not adapted to colonizing naturally disturbed sites.

The thickness of gravel fill that should be left in place during gravel removal and the amount of acreage of gravel that should be removed after the oilfields are abandoned are problematic and contentious issues. Because ice is present in the underlying permafrost, removal of all the insulating gravel causes thermal instability in the newly exposed surface and can result in thaw settlement. At one experimental site (OSP Access Road), the surface has subsided $10-20 \mathrm{~cm}$ below the water's surface, even though 10-20 cm of gravel was left on the former roadbed (Jorgenson and Kidd, 1991). At several other sites that have 10$20 \mathrm{~cm}$ of gravel remaining, differential subsidence has left flooded troughs and small depressions. Although some subsidence can be beneficial by creating a mosaic of moist and wet habitats, excessive subsidence reduces the options for plant cultivation and can create channels or basins that interrupt subsurface movement and cause channelization of water movement that may affect surrounding wetlands.

The amount of subsidence depends on the heat balance of the surface and on the amount of underlying ice in the permafrost. Unfortunately, determining how much ice is present and predicting how much settlement will occur is site specific and requires expensive data collection techniques. Given the expense and impracticality of such determinations, leaving 20 to $30 \mathrm{~cm}$ of gravel probably is a good compromise that will compensate for some settlement yet will provide adequate conditions for restoring wetlands. Removal of all gravel in a few patches within the remaining gravel will create a mosaic of wet and moist surfaces that can be colonized readily by wetland species.

Agreement on how much acreage of gravel should be removed upon abandonment of oilfield facilities may be more problematic than determining how thick the remaining gravel should be. In addition to the problems associated with subsidence, other problems associated with gravel removal include interest from local residents in maintaining roads for access and subsistence hunting, finding acceptable places to put the gravel after removal, and cost. Gravel could be put back in the mine sites, but there are competing interests in using them for fish habitat. Finally, the expense of field-wide gravel removal would be enormous and the benefits may not justify the cost. Estimates of the cost of removing all roads and pads after the oilfields are abandoned range in the hundreds of millions of dollars.

Given the high value of restoring wetland habitats for wildlife and the opposing high costs of gravel removal, intermediate strategies short of field-wide removal of all gravel may be appropriate. For example, during further expansion of oilfield facilities, some gravel could be removed cost effectively from old abandoned roads and pads and recycled as new fill. Already, recycling of gravel has been required by regulatory agencies for some recent developments. Later, after abandonment of the oilfield, the expense of gravel removal may be justified to eliminate the impounding effects of roads across drainages and to restore areas of high-quality habitat.

\section{Wetland Restoration After Minor Disturbances}

Many other types of disturbances associated with oilfield development are considered to have minor effects, because they cause only minor modifications to pedologic and hydrologic characteristics. These minor disturbances include damage to the tundra from off-road vehicles and seismic surveys, thin gravel coverage from road washouts, road traffic and snow removal, and coverage of tundra plants by road dust. Construction of roads and pads also can cause impoundments because of the low relief and indistinct drainage patterns on the coastal plain.

Off-road traffic is limited to rare accidents of vehicles running off the road and to occasional use of Rolligons (vehicles with balloon tires) to transport equipment to remote sites. Near Drill Site 5, where numerous Rolligon tracks had compressed the tundra's surface while assisting a mobile drilling rig, the deeper tracks were backfilled with organic topsoil and were fertilized. At another site, where a tracked vehicle crossed dry tundra during an oil-recovery drill, the bare tracks were fertilized to assist natural recovery (Jorgenson and Kidd, 1991).

Thin gravel cover $(0-10 \mathrm{~cm})$ is widespread adjacent to roads and pads because of traffic and snow removal activities. This thin layer of gravel has been removed at numerous sites by using backhoes, large-diameter vacuum hoses, and hand labor (Barnes, 1990; Miller, 1990; Jorgenson and Kidd, 1991). After removal, numerous plant cultivation techniques have been tried, including fertilization to assist natural colonization, seeding with native grasses, and transplanting of tundra plugs. Although data are not yet available for comparing treatments, natural colonization should be sufficient to restore wetland vegetation in a timely manner. At Drill Site 2B, where a thin layer of gravel was partially removed by hand after a road washout covered the adjacent tundra, natural recovery without fertilization has been satisfactory: mean vascular plant cover has increased from $3 \%$ to $22 \%$ after 7 years, primarily through colonization by water sedge (Carex aquatilis), tall cottongrass (Eriophorum angustifolium), and pendent grass (Arctophila fulva) (Table 2).

Impoundments are a large, indirect effect of construction of gravel roads and pads and cover as much as $22 \%$ of the area in densely developed portions of the Prudhoe Bay Oilfield (Walker et al., 1987). However, in the newer Kuparuk Oilfield, which has a more varied topography than Prudhoe Bay, impoundments are uncommon. The effects of the impoundments are highly variable and can range from temporary impoundments that delay plant growth to deep, permanent impoundments that resemble natural deep, open lakes. We are not aware of any studies of attempts to rehabilitate such impounded areas. In a study of the natural recovery of 10 - to 20-year-old impoundments, however, densities of aquatic invertebrates and ducks were higher in impoundments than in similarly sized natural ponds (Kertell, 1993). Removal of gravel in selected areas could be used to eliminate impoundments and promote the natural recovery of the inundated tundra. 


\section{Remediation of Contaminated Sites}

The cleanup of contaminated areas (i.e., remediation) to levels safe for fish and wildlife, human health, and plant growth has been a growing segment of land rehabilitation efforts. Spills of crude oil, diesel fuel, seawater, brine, and glycol and the surface disposal of reserve pit muds are examples of contaminants that require remediation.

In response to the establishment and enforcement of cleanup standards for petroleum-contaminated soils in Alaska(A.D.E.C., 1991), the development and application of remediation technology in the Arctic has been rapid. Although numerous technologies are being investigated, bioremediation and thermal treatment have received the most effort.

Bioremediation technology is undergoing major development because of its low costs and historical application in the Arctic, where numerous attempts were made to enhance microbial degradation of petroleum hydrocarbons even before the term "bioremediation" was coined. In 1977, fertilization was used to promote the biodegradation of leaded gasoline in pond sediments that were contaminated by a 210000 -L spill at Barrow (Horowitz and Atlas, 1978). Total petroleum hydrocarbon(TPH) concentrations were reduced by $98 \%$ after one summer of treatment, but the relative contributions of biodegradation and volatilization were unknown. At Check Valve 23 on the TransAlaska Pipeline, where about $127000 \mathrm{~L}$ of crude oil were recovered out of $240000 \mathrm{~L}$ spilled, tillage and fertilization reduced the oil content by $88 \%$ after three years of treatment (Brendel and Eschenback, 1985). Fertilization also was somewhat effective on a crude oil spill at Norman Wells in the Northwest Territories, reducing soil TPH levels by $42 \%$ after three years of treatment (Westlake et al., 1978).

Recently, numerous in situ bioremediation, landfarming, bioventing, and soil washing projects have been initiated in the North Slope oilfields. Fertilization, aeration, and hydrologic manipulation were used to achieve a $90 \%$ reduction in TPH after three years for a crude-oil spill on 0.6 ha of tundra near Drill Site $2 \mathrm{U}$ in the Kuparuk Oilfield (Jorgenson and Cater, 1992). After excavation and incineration of soils heavily contaminated with crude oil at the S.E. Eileen Exploratory Well Site, fertilization, tilling with an agricultural disker and a hand-operated rototiller (Fig. 10), and watering and dewatering with a gas-powered pump to control groundwater levels also were used to promote biodegradation of the remaining hydrocarbons on 2.2 ha of tundra (Jorgenson and Cater, 1992). TPH levels decreased by $90 \%$ after two years. Similar treatments achieved a $64 \%$ reduction in hydrocarbon levels in diesel-contaminated gravel in Prudhoe Bay during the first year of treatment (Evans et al., 1991). At another site, these three types of treatment reduced TPH levels in diesel-contaminated gravel to below Alaska's cleanup standard in one summer after the gravel was excavated and treated on a plastic liner (Galloway, 1991). Fertilization and watering were used to enhance in situ biodegradation of oil and diesel in a gravel pad at Pt. Thompson, achieving a $60 \%$ reduction in TPH levels (Liddel et al., 1991).

A mobile thermal remediation unit was brought to Deadhorse in 1991 to incinerate the large volume of soil excavated from the
S.E. Eileen site (Jorgenson and Cater, 1992). Since its arrival in the oilfield, this thermal remediation unit has been used to treat petroleum-contaminated soils from many sites (e.g., Barnes and Griffiths, 1993).

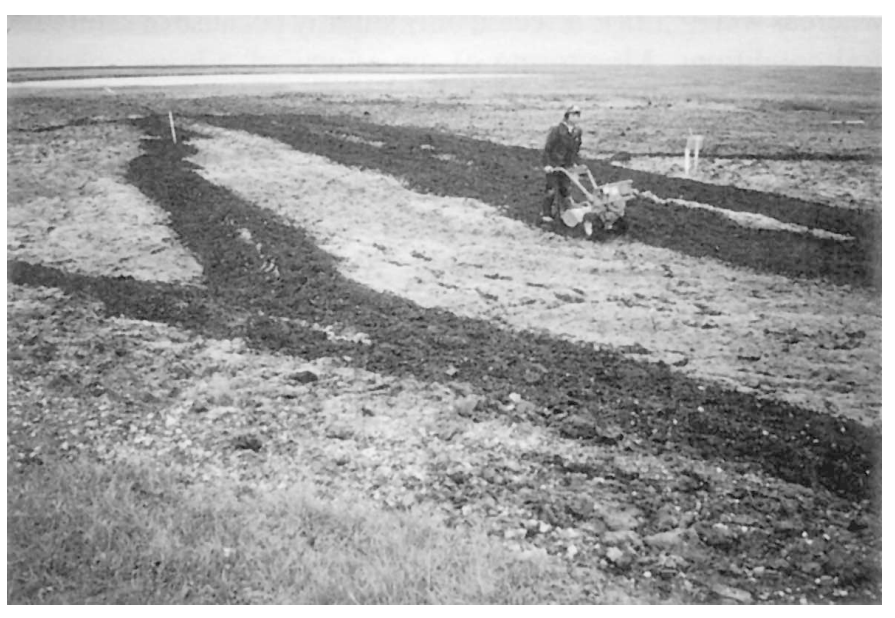

FIG. 10. View of rototilling tundra soil that had been contaminated with crude oil from a spill that occurred in 1969. In 1990, heavily contaminated gravel fill and tundra soil were removed from the site, and tilling was used to promote biodegradation of the remaining hydrocarbons.

Remediation of old reserve pits used to contain drilling muds and fluids also has been a top concern for regulatory agencies and industry. Reserve pits that were created using older drilling technology are of concern because they contain numerous chemical additives (e.g., diesel fuel, potassium chloride, corrosion inhibitors, bactericides, arsenical compounds, and heavy metals) used to control the properties of drilling muds (Lawhead et al., 1992). West and Snyder-Conn (1987) found that hardness, alkalinity, turbidity, chromium, barium, arsenic, and nickel were elevated in tundra ponds that were adjacent to reserve pits. Concentrations of TPH measured in reserve pit sediments ranged from 146 to 837 $\mathrm{mg} \cdot \mathrm{kg}^{-1}$ (Woodward et al., 1988).

Because of concerns for potential health risks to wildlife, drilling practices have been evolving to reduce the exposure of wildlife to drilling muds. Beginning in 1984, below-grade burial and encapsulation in permafrost were used to contain drilling muds at some drill sites and exploratory well sites. By 1991, reinjection of drilling muds into well annuli became standard practice. At recent exploratory well sites that have been drilled from an ice pad and where drilling muds were reinjected, visual evidence of surface disturbance is minimal.

Disposal of drilling muds during closure of old reserve pits will decrease further the potential exposure of wildlife to contaminants. The feasibility and economics of grinding up drill cuttings and disposing them down deep injection wells are being investigated in both the Kuparuk and the Prudhoe Bay Oilfields. Another approach has been used recently for disposing of muds from Drill Site 3 by excavating a large pit on the tundra and encapsulating the muds in permafrost below the zone of annual thawing. While this technique is effective at isolating the contaminants, it disturbs additional tundra and raises concerns over the long-term fate of the contaminants. 
Finally, the transportation of seawater in pipelines for injection into oil formations to maintain reservoir pressure and the use of brines during drilling allow the accidental spillage of salts that are toxic to tundra ecosystems. Simmons et al. (1983) found that dry tundra is particularly sensitive to seawater contamination, whereas wet tundra is affected only slightly because of saturated soil conditions. Monitoring of the effects of a brine solution spilled during drilling in 1982 at Drill Site 1G found that vegetation was totally killed by higher concentrations near the pad (Jorgenson et al., 1987). Ten years after the spill, the saltkilled tundra has been colonized rapidly by salt-tolerant species, particularly Dupontia. At a site contaminated by seawater that leaked from a pipeline near CPF-3 in midwinter 1990, removal of contaminated snow and flushing of the surface after snowmelt prevented all but slight damage to the moist and wet tundra.

\section{CONCLUSIONS}

Results from our long-term research program and from numerous other arctic projects are providing a growing body of information on techniques that can be used to rehabilitate disturbed land for fish and wildlife habitat. We have organized these techniques into six basic strategies that cover almost all aspects of oilfield development, including gravel mine sites and overburden stockpiles, gravel roads and pads, indirect disturbances such as gravel spray and road dust, and contaminants. Efforts to flood abandoned mine sites to create habitat for overwintering fish have found that sites connected to streams are rapidly colonized by numerous fish species. The creation of wetlands on overburden stockpiles associated with mine sites appears feasible through the transplanting of aquatic graminoids and invertebrates. For minor off-road disturbances, natural recovery over time appears to be the best strategy.

More problematic, however, is the rehabilitation of thick gravel fill, which is the predominant type of disturbed terrain associated with oil development. While the use of organic topsoil has been found to greatly improve productivity, sustain growth over a long period, and allow for a broad range of colonizing plant species, little topsoil is available for land rehabilitation. Without topsoil application, the long-term success of seeded native grasses, assisted with fertilization, appears poor. Consequently, alternative techniques for revegetating thick gravel fill that need further investigation are the use of sewage sludge and the use of nitrogen-fixing legumes and other plants that are adapted to the severe environment. A more expensive alternative to revegetating the gravel in place is removing the gravel to promote the restoration of wetland communities. The removal of gravel helps restore soil properties and the hydrologic regime to conditions similar to those existing before fill placement, facilitating the establishment of some of the original plant species. However, uncertainty over community development after gravel removal, thaw settlement, what to do with the gravel, and the high cost of removal, make this a controversial strategy.

Finally, numerous techniques are being investigated to remediate contaminated soils, and many techniques have been shown to reduce contaminants to levels acceptable to regulatory agencies. Some of the outstanding questions regarding remediation relate to which techniques are the most economical and which minimize additional ecological damage. Although most of the land rehabilitation research has been conducted on the Arctic Coastal Plain in northern Alaska, most of the techniques are applicable to other arctic regions with minor changes in the assemblage of key species, particularly shrubs. Overall, while much work remains to be done to improve the diversity, productivity, and self-sustaining nature of rehabilitated land, numerous techniques are available that can be organized into broader strategies for treating the wide range of degraded lands. How these treatments are applied and in what combinations, however, will ultimately depend on their relative costs and benefits-issues that industry and regulatory agencies will have a difficult time addressing.

\section{ACKNOWLEDGEMENTS}

This review and much of the work we refer to were funded by ARCO Alaska, Inc. We would like to thank Alan Schuyler, Larry Krizan, RodHoffman, and RobertElder,FieldEnvironmental Directors, ARCO, for coordinating many of these projects. We also thank Timothy C. Cater, Janet G. Kidd, Laura L. Jacobs, Lee A. Nix, and Brian K. Lance for their contributions to many of the research projects that we described. Allison Zusi-Cobb provided graphic assistance. Robert B. Day, Stephen M. Murphy, Betty A. Anderson, Roseann V. Densmore, and Donald A. Walker provided many constructive comments on the manuscript.

\section{REFERENCES}

ABELE, G., BROWN, J., and BREWER, M.C. 1984. Long-term effects of off-road vehicle traffic on tundra terrain. Journal of Terramechanics 20:283-294.

A.D.E.C. (ALASKA DEPARTMENT OF ENVIRONMENTAL CONSERVATION). 1991. Interim guidance for non-UST contaminated soil cleanup levels. Juneau, Alaska. 17 p.

BARNES, T.W. 1990. Mine site rehabilitation - BP Exploration. Abstract in Proceedings of the Terrestrial Studies Workshop, 16-17 November 1990, Anchorage, Alaska. Available at BP Exploration (Alaska) Inc., 900 E. Benson Blvd., Anchorage, Alaska 99519, U.S.A.

BARNES, T.W., and GRIFFITHS, L.A. 1993. Cleanup of Niakuk Island No. 1 and incineration of diesel contaminated soils for reuse. Abstract in Proceedings of the Third Annual Terrestrial Studies Workshop, 22-23 February 1993, Anchorage, Alaska. Available at BP Exploration (Alaska) Inc., 900 E. Benson Blvd., Anchorage, Alaska 99519, U.S.A.

BENDOCK, T.N. 1977. Beaufort Sea estuarine fishery study (RU233). In: Environmental assessment of the Alaska Continental Shelf. Final Reports of Principal Investigators. Vol. 4: Biological Studies. Available from U.S. Department of Commerce, Anchorage, Alaska 99501, U.S.A. 670-729. 
BERGMAN, R.D., HOWARD, R.L., ABRAHAM, K.F., and WELLER, M.W. 1977. Waterbirds and their wetland resources in relation to oil development. Resource Publication No. 129. Washington, D.C.: U.S. Fish and Wildlife Service. 38 p.

BILLINGS, W.D. 1987. Constraints to plant growth, reproduction, and establishment in arctic environments. Arctic and Alpine Research 19(4):357-365.

BLISS, L. C., and CANTLON, J.E. 1957. Succession on river alluvium in northern Alaska. American Midland Naturalist 58:452-469.

BRENDEL, J.E., and ESCHENBACK, T.G. 1985. Check valve 23 revegetation study. In: Lewis, M.L., ed. Northern hydrocarbon developmentenvironmental problem solving: Proceedings of eighth annual meeting of the International Society of Petroleum Industry Biologists, 24-26 September 1985, Banff, Alberta. 230-239.

CARGILL, S.M., and CHAPIN III, F.S. 1987. Application of successional theory to tundra restoration: A review. Arctic and Alpine Research 19:366-372.

CATER, T.C., and JORGENSON, M.T. 1993. Land rehabilitation studies in the Kuparuk Oilfield, Alaska, 1992. Unpubl. Final Report prepared by Alaska Biological Research, Inc., Fairbanks, Alaska. Available from ARCO Alaska, Inc., P.O. Box 100360, Anchorage, Alaska 99510, U.S.A. 38 p.

CATER, T.C., and JORGENSON, M.T. 1994. Land rehabilitation studies in the Kuparuk Oilfield, Alaska, 1993. Unpubl. Final Report prepared by Alaska Biological Research, Inc., Fairbanks, Alaska. Available from ARCO Alaska, Inc., P.O. Box 100360, Anchorage, Alaska 99510, U.S.A. 39 p.

CHAPIN III, F.S. 1987. Environmental controls over growth of tundra plants. Ecological Bulletins 38:67-76.

CHAPINIII,F.S., and SHAVER, G.R. 1981.Changes in soil properties and vegetation following disturbance of Alaskan arctic tundra. Journal of Applied Ecology 18:605-617.

CHAPIN III, F.S., and SHAVER, G.R. 1985. Arctic. In: Chabot, B.F., and Mooney, H.A., eds. Physiological ecology of North American plant communities. London: Chapman and Hall. 16-40.

CHAPIN III, F.S., JEFFERIES, R.L., REYNOLDS, J.F., SHAVER, G.R., and SVOBODA, J. 1992. Arctic plant physiological ecology in an ecosystem context. In: Chapin, F.S., Jefferies, R.L., Reynolds, J.F., Shaver, G.R., and Svoboda, J., eds. Arctic ecosystems in a changing climate. New York: Academic Press. 441-449.

DENSMORE, R.V. 1992. Succession on an Alaskan tundra disturbance with and without assisted revegetation with grass. Arctic and Alpine Research 24:238-243.

DENSMORE, R.V., NEILAND, B.J.,ZASADA, J.C., and MASTERS, M.A. 1987. Planting willow for moose habitat restoration on the North Slope of Alaska, U.S.A. Arctic and Alpine Research 19: 537-543.

DINGMAN, S.L., BARRY, R.G., WELLER, G., BENSON, C., LeDREW, E.F., and GOODWIN, C. 1980. Climate, snow cover, microclimate, and hydrology. In: Brown, J., Miller, P.C., Tieszen, L.L., and Bunnell, F.L., eds. An arctic ecosystem: The coastal tundra at Barrow, Alaska. Stroudsburg, Pennsylvania: Dowden, Hutchinson, and Ross. 30-65.

EBERSOLE, J.J. 1987. Short-term vegetation recovery at an Alaskan arctic coastal plain site. Arctic and Alpine Research 19:442-450.

EVANS, D., ELDER, R., and HOFFMAN, R. 1991. Bioremediation of diesel contamination at the Surfcote Pad, Prudhoe Bay Unit
E.O.A., Alaska. Abstract in Proceedings of the Soil Remediation Workshop, 19-20 November 1991, Anchorage, Alaska. Available at BP Exploration (Alaska) Inc., 900 Benson Blvd., Anchorage, Alaska 99519, U.S.A.

EVERETT, K.R., MURRAY, B.M., MURRAY, D.F., JOHNSON, A.L., LINKINS, A.E., and WEBBER, P.J. 1985. Reconnaissance observations on long-term natural vegetation recovery in the Cape Thompson region, Alaska, and additions to the checklist of flora. CRREL Report 85-11. Hanover, New Hampshire: Cold Regions Research Engineering Laboratory. 76 p.

FELIX, N.A., and RAYNOLDS, M.K. 1989. The effects of winter seismic trails on tundra vegetation in northeastern Alaska, U.S.A. Arctic and Alpine Research 21:188-202.

FRANCOIS, D.K., and GACHTER, R.A. 1992. Alaska update, February 1990-April 1992: Outer continental shelf oil and gas activities. OCS Information Report MMS 92-0053.

GALLOWAY, G. 1991. Appropriate hydrocarbon cleanup levels and successful bioremediation on the North Slope. Abstract in Proceedings of the Soil Remediation Workshop, 19-20 November 1991, Anchorage, Alaska. Available at BP Exploration (Alaska) Inc., 900 Benson Blvd., Anchorage, Alaska 99519, U.S.A.

GARTNER, B.L., CHAPIN III, F.S., and SHAVER, G.R. 1986. Reproduction of Eriophorum vaginatum by seed in Alaskan tussock tundra. Journal of Ecology 20:965-980.

HEMMING, C.R. 1989. Gravel pits to fish ponds. Alaska Fish and Game 21:36-37.

. 1990. Fisheries investigations of flooded North Slope gravel mine sites, 1989. Technical Report 90-2. Juneau, Alaska: Alaska Department of Fish and Game.

-1992. Fish and habitat investigations of flooded North Slope gravel mine sites, 1990. Technical Report 91-3. Juneau, Alaska: Alaska Department of Fish and Game. 44 p.

HEMMING, C.R., WEBER, P.K., and WINTERS, J.F. 1989. Limnological and fisheries investigations of flooded North Slope gravel mine sites, 1988. Technical Report 89-1. Juneau, Alaska: Alaska Department of Fish and Game. 60 p.

HOBBIE, J.E. 1984. The ecology of tundra ponds of the Arctic Coastal Plain: A community profile. ReportFWS/OBS-83/25. Washington, D.C.: U.S. Fish and Wildlife Serv. 52 p.

HOROWITZ, A., and ATLAS, R.M. 1978. Hydrocarbons and microbial activities in sediment of an arctic lake one year after contamination with leaded gasoline. Arctic 31:180-191.

JACOBS,L.L., JORGENSON, M.T., and CATER, T.C. 1993. Wetland creation and revegetation on an overburden stockpile at Mine Site D, Kuparuk Oilfield, Alaska, 1992. Unpubl. Final Report prepared by Alaska Biological Research, Inc., Fairbanks, Alaska. Available at ARCO Alaska, Inc., P.O. Box 100360, Anchorage, Alaska 99510, U.S.A.

JOHNSON, L.A. 1981. Revegetation and selected terrain disturbances along the Trans-Alaska Pipeline. CRREL Report 81-12. Hanover, New Hampshire: Cold Regions Research Engineering Laboratory. 115 p.

JORGENSON, M.T. 1988a. Rehabilitation studies in the Kuparuk Oilfield, Alaska, 1987. Unpubl. Final Report prepared by Alaska Biological Research, Inc., Fairbanks, Alaska. Available at ARCO Alaska, Inc., P.O. Box 100360, Anchorage, Alaska 99510, U.S.A. 90 p. 
. 1988b. Revegetation of the Lake State 1 exploratory well site, Prudhoe Bay, Alaska, 1987. Unpubl. Final Report prepared by Alaska Biological Research, Inc., Fairbanks, Alaska. Available at ARCO Alaska, Inc., P.O. Box 100360, Anchorage, Alaska 99510, U.S.A. 74 p.

. 1989. An overview of rehabilitation research in the Kuparuk Oilfield. Unpubl. Final Report prepared by Alaska Biological Research, Inc., Fairbanks, Alaska. Available at ARCO Alaska, Inc., P.O. Box 100360, Anchorage, Alaska 99510, U.S.A. 65 p. JORGENSON, M.T., and CATER, T.C. 1991. Land rehabilitation studies in the Kuparuk Oilfield, Alaska, 1990. Unpubl. Final Report prepared by Alaska Biological Research, Inc., Fairbanks, Alaska. Available at ARCO Alaska, Inc., P.O. Box 100360, Anchorage, Alaska 99510, U.S.A. 51 p.

JORGENSON, M.T., and CATER, T.C. 1992. Cleanup and bioremediation of a crude-oil spill at Prudhoe Bay, Alaska. In: Proceedings of the Fifteenth Arctic and Marine Oil Spill Program Technical Seminar, 10-12 June 1992, Edmonton, Alberta. Ottawa: Environment Canada. 715-722.

JORGENSON, M.T., and KIDD, J.G. 1991. Land rehabilitation studies in the Prudhoe Bay Oilfield, Alaska, 1990. Unpubl. Final Report prepared by Alaska Biological Research, Inc., Fairbanks, Alaska. Available at ARCO Alaska, Inc., P.O. Box 100360, Anchorage, Alaska 99510, U.S.A. 56 p.

JORGENSON, M.T., CATER, T.C., and JACOBS, L.L. 1992. Wetland creation and revegetation on overburden in arctic Alaska. In: Sukumar, B., and Nelson, M.G., eds. Mining in the Arctic: Proceedings of the Second International Symposium on Mining in the Arctic, 19-22 July 1992, Fairbanks, Alaska. Rotterdam, Netherlands: A.A. Balkema. 265-275.

JORGENSON, M.T., CATER, T.C., KIDD, J.G., JACOBS, L.L., and JOYCE, M.R. 1994. Techniques for rehabilitating lands disturbed by oil development in the Arctic. In: Proceedings of the Eleventh High Altitude Revegetation Workshop, 16-18 March 1994, Colorado State University, Ft. Collins, Colorado.

JORGENSON, M.T., HEFFERNAN, T.T., and LANCE, B.K. 1990. Land rehabilitation studies in the Kuparuk Oilfield, Alaska, 1989. Unpubl. Final Report prepared by Alaska Biological Research, Inc., Fairbanks, Alaska. Available at ARCO Alaska, Inc., P.O. Box 100360, Anchorage, Alaska 99510, U.S.A. 132 p.

JORGENSON, M.T., KIDD, J.G., and CATER, T.C. 1992. Rehabilitation of a thick gravel pad using snow capture and topsoil addition, Drill Site 13, Prudhoe Bay Oilfield, Alaska, 1991. Unpubl. Final Report prepared by Alaska Biological Research, Inc., Fairbanks, Alaska. Available at ARCO Alaska, Inc., P.O. Box 100360, Anchorage, Alaska 99510, U.S.A. 19 p.

JORGENSON, M.T., ROBUS, M.A., ZACHEL, C.O., and LAWHEAD, B.E. 1987. Effects of a brine spill on tundra vegetation and soil in the Kuparuk Oilfield, Alaska. Unpubl. Final Report prepared by Alaska Biological Research, Inc., Fairbanks, Alaska. Available at ARCO Alaska, Inc., P.O. Box 100360, Anchorage, Alaska 99510, U.S.A. 147 p.

JOYCE, M.R., and JORGENSON, M.T. 1991. Land rehabilitation research on the Arctic Slope of Alaska. Restoration and Management Notes 8:129-130.

JOYCE, M.R., RUNDQUIST, L.A., and MOULTON, L.L. 1980. Gravel removal guidelines manual for arctic and subarctic floodplains. ReportFWS/OBS-80/09. Washington,D.C.:U.S. Fish and Wildlife Service.

KERSHAW, G.P., and KERSHAW, L.J. 1987. Successful plant colonizers on disturbances in tundra areas of northwestern Canada. Arctic and Alpine Research 19:451-460.

KERTELL, K. 1993. Waterbird use and secondary productivity of impounded wetlands in the Prudhoe Bay Oil Field. Abstract in Proceedings of the Third Annual Terrestrial Studies Workshop, 22-23 February 1993. Available at BP Exploration (Alaska) Inc., 900 Benson Blvd., Anchorage, Alaska 99519, U.S.A.

KIDD, J.G., and JORGENSON, M.T. 1992. Land rehabilitation studies in the Prudhoe Bay Oilfield, Alaska, 1991. Unpubl. Data Report prepared by Alaska Biological Research, Inc., Fairbanks, Alaska. Available at ARCO Alaska, Inc., P.O. Box 100360, Anchorage, Alaska 99510, U.S.A. 12 p.

KIDD, J.G., JORGENSON, M.T., JACOBS, L.L., and CATER, T.C. 1994. Ecological restoration of the Prudhoe Bay State No. 2 Exploratory Well Site, Prudhoe Bay, Alaska, 1993. Unpubl. Final Report prepared by Alaska Biological Research, Inc., Fairbanks, Alaska. Available at ARCO Alaska, Inc., P.O. Box 100360, Anchorage, Alaska 99510, U.S.A.

KLEBESADEL, L.S. 1971. Native Alaskan legumes studied. Agroborealis 3(1):9-11.

LAWHEAD, B.E., BISHOP, S.C., and STUBBLEFIELD, W.A. 1992. Caribou, drilling muds, and geophagy: A literature review and synthesis. Unpubl. Final Report by Alaska Biological Research, Inc., Fairbanks, Alaska and ENSR Consulting and Engineering, Fort Collins, Colorado. Available at BP Exploration (Alaska) Inc., 900 Benson Blvd., Anchorage, Alaska 99519, U.S.A. 21 p.

LAWSON, D.E., BROWN, J., EVERETT, K.R., JOHNSON, A.W., KOMARKOVA, V., MURRAY, B.M., MURRAY, D.F., and WEBBER, P.J. 1978. Tundra disturbances and recovery following the 1949 exploratory drilling, Fish Creek, Alaska. CRREL Report 78-28. Hanover, New Hampshire: Cold Regions Research Engineering Laboratory. $81 \mathrm{p}$.

LIDDELL, B., SMALLBECK, D.R., and RAMERT, P.C. 1991. Arctic bioremediation: A case study. Abstract in Proceedings of the Soil Remediation Workshop, 19-20 November 1991, Anchorage, Alaska. Available at BP Exploration (Alaska) Inc., 900 Benson Blvd., Anchorage, Alaska 99519, U.S.A.

McKENDRICK, J.D.1986. Final cleanup at selected (1975-1981) well sites, sampling and testing of waters and bottom muds in the reserve pits and the recording of tundra plant responses on the National Petroleum Reserve in Alaska, Volume III, Recording of plant responses. Unpubl. Final Report prepared by Nuera Reclamation Co., Anchorage, Alaska. Available at U.S. Geological Survey, Anchorage, Alaska 99501, U.S.A. 225 p.

.1987. Plant succession on disturbed sites, North Slope, Alaska. Arctic and Alpine Research 19:554-565.

—. 1990. Long-term revegetation assessment. Abstract in Proceedings of the North Slope Terrestrial Studies Workshop, 1516November 1990, Anchorage, Alaska. Available at BPExploration (Alaska) Inc., 900 Benson Blvd., Anchorage, Alaska 99519, U.S.A. 1991. Arctic tundra rehabilitation —observations of progress and benefits to Alaska. Agroborealis 23:29-40.

McKENDRICK, J.D., SCORUP, P.C., FISCUS, W.E., TURNER, G., FOSBERG, M.A., and SHARP, L.E. 1993. Habitat and biological 
changes over time on exploratory well sites in NPRA, 1984-1992. Abstract in Proceedings of the Third Annual Terrestrial Studies Workshop, 22-23 February 1993, Anchorage, Alaska. Available at BP Exploration (Alaska) Inc., 900 Benson Blvd., Anchorage, Alaska 99519, U.S.A.

MEEHAN, R. 1986. Impact of oil development on shorebirds, Prudhoe Bay, Alaska. Ph. D. dissertation, University of Colorado, Boulder, Colorado.

MEEHAN, R., and JENNINGS, J. 1988. Characterization and value ranking of waterbird habitat on the Colville River Delta, Alaska. Unpubl. report. Available at U.S. Fish and Wildlife Service, 1011 E. Tudor Road, Anchorage, Alaska 99503, U.S.A. 105 p.

MILLER, M. 1990. Remedial gravel removal in the Prudhoe Bay Oilfield-1990. Abstract in Proceedings of the Terrestrial Studies Workshop, 16-17 November 1990, Anchorage, Alaska. Available at BP Exploration (Alaska) Inc., 900 Benson Blvd., Anchorage, Alaska 99519, U.S.A.

MITCHELL, W.W. 1979. Three varieties of native Alaskan grasses for revegetation purposes. Circular 32, Agricultural Experimental Station, University of Alaska, Fairbanks, Alaska. 9 p.

MOORE, N. 1991. Studies on the techniques for revegetation with Arctophila fulva. Unpubl. Final Report prepared by Plant Materials Center, Alaska Department of Natural Resources, Palmer, Alaska. Available at ARCO Alaska, Inc., P.O. Box 100360, Anchorage, Alaska 99510, U.S.A.

. 1993. Native seeds and Arctophila. Abstract in Proceedings of the Third Annual Terrestrial Studies Workshop, 22-23 February 1993, Anchorage, Alaska. Available at BP Exploration (Alaska) Inc., 900 Benson Blvd., Anchorage, Alaska 99519, U.S.A.

NATIVE PLANTS, INC. 1980. Revegetation assessment for the proposed Alaska Natural Gas Transportation System, II: Field assessment of TAPS revegetation. Unpubl. Final Report by Native Plants, Inc., Salt Lake City, Utah. Available at Fluor North west, Inc., 3333 Michelson Dr., Irvine, California 92730, U.S.A. 218 p.

PETERSON, K.M., and BILLINGS, W.D. 1980. Tundra vegetational patterns and succession in relation to microtopography near Atkasook, Alaska. Arctic and Alpine Research 12:473-482.

POLLARD, R., RODRIGUES, R., and WILKINSON, R.C. 1990. Wildlife use of disturbed habitats in arctic Alaska. Unpubl. Final Report prepared by LGL Alaska Research Associates, Inc. Available at BP Exploration (Alaska) Inc., 900 Benson Blvd., Anchorage, Alaska 99509, U.S.A. 111 p.

POST, R.A. 1990. Effects of petroleum development in Alaskan wetlands: A critique. Technical Report 90-3. Juneau, Alaska: Alaska Department of Fish and Game. 112 p.

RYDEN, B.E. 1981. Hydrology of northern tundra. In: Bliss, L.C., Heal, O.W., and Moore, J.J., eds. Tundra ecosystems: A comparative analysis. Cambridge: Cambridge University Press. 115-137.

SCHMIDT, D.R., GRIFFITHS, W.B., AND MARTIN, L.R. 1989. Overwintering biology of anadromous fish in the Sagavanirktok River Delta, Alaska. Biological Papers of the University of Alaska, Fairbanks, Alaska, No. 24. 55-74.

SIMMONS, C.L., EVERETT, K.R., WALKER, D.A., LINKINS, A.E., and WEBBER, P.J. 1983. Sensitivity of plant communities and soil flora to seawater spills, Prudhoe Bay, Alaska. CRREL Report 83-24. Hanover, New Hampshire: Cold Regions Research Engineering Laboratory. 35 p.
SLAUGHTER, C., MELLOR, M., SELLMAN, P., BROWN, J., and BROWN, L. 1975. Accumulating snow to augment the freshwater supply for Barrow, Alaska. CRREL Report 217. Hanover, New Hampshire: Cold Regions Research Engineering Laboratory. 21 p.

THOMAN, R.L. 1990. The climate of Prudhoe Bay, Alaska. NOAA Technical Memorandum NWS AR-40. Anchorage, Alaska: National Weather Service. 33 p.

TROY,D.M. 1985. Prudhoe Bay waterflood environmental monitoring program terrestrial studies - 1984. Unpubl. Final Report prepared by Envirosphere, Inc. Available at U.S. Army Corps of Engineers, Alaska District, Anchorage, Alaska, U.S.A. 163 p.

. 1991. Bird use of disturbed tundra at Prudhoe Bay, Alaska: Bird and nest abundance along the abandoned peat roads, 19881989. Unpubl. Final Report prepared by Troy Ecological Research Associates, Anchorage, Alaska. Available at BP Exploration (Alaska) Inc., 900 Benson Blvd., Anchorage, Alaska 99519, U.S.A. 57 p.

WALKER,D.A., and ACEVEDO, W. 1987. Vegetation and a Landsatderived land cover map of the Beechey Point Quadrangle, Arctic Coastal Plain, Alaska. CRREL Report 87-5. Hanover, New Hampshire: Cold Regions Research Engineering Laboratory. 63 p.

WALKER, D.A., and EVERETT, K.R. 1987. Road dust and its environmental impact on Alaskan taiga and tundra. Arctic and Alpine Research 19:479-489.

WALKER, D.A., and WALKER, M.D. 1991. History and pattern of disturbance in Alaskan arctic terrestrial ecosystems: A hierarchical approach to analyzing landscape change. Journal of Applied Ecology 28:244-276.

WALKER, D.A., CATE, D., BROWN, J., and RACINE, C. 1987. Disturbance and recovery of arctic Alaskan tundra terrain: A review of recent investigations. CRREL Report 87-11. Hanover, New Hampshire: Cold Regions Research Engineering Laboratory. 63 p.

WALKER, D.A., EVERETT, K.R., WEBBER, P.J., and BROWN, J. 1980. Geobotanical atlas of the Prudhoe Bay region, Alaska. CRREL Report 80-14. Hanover, New Hampshire: Cold Regions Research Engineering Laboratory. 69 p.

WALKER, D.A., WEBBER, P.J., BINNIAN, E.F., EVERETT, K.R., LEDERER, N.D., NORDSTRAND, E.A., and WALKER, M.D. 1987. Cumulative impacts of oil fields on northern Alaskan landscapes. Science 238:757-761.

WEST, R.L., and SNYDER-CONN, E. 1987. Effects of Prudhoe Bay reserve pit fluids on water quality and macroinvertebrates of arctic tundra ponds in Alaska. Biological Report 87(7). Washington, D.C.: U.S. Fish and Wildlife Service. 48 p.

WESTLAKE, D.W., JOBSON, A.M., and COOK, F.D. 1978. In situ degradation of oil in a soil of the boreal region of the Northwest Territories. Canadian Journal of Microbiology 24:254-260.

WINTERS, J.F. 1990. A transplant of arctic grayling to a flooded gravel mine site in the Kuparuk River Oilfield. Technical Report 90-4. Juneau, Alaska: Alaska Department of Fish and Game. 26 p.

WOODWARD, D.F., SNYDER-CONN, E., and RILEY, R.G. 1988. Drilling fluids and the arctic tundra of Alaska: Assessing contamination of wetlands habitat and the toxicity to aquatic invertebrates and fish. Archives of Environmental Contamination and Toxicology 17:683-697.

WRIGHT, S. 1987. Initial data and observations obtained from the 2Caccess spur and Mine Site D herbaceous evaluation plots located in the Kuparuk Unit. Unpubl. Final Report prepared by Plant Materials 
Center, Alaska Department of Natural Resources, Palmer, Alaska. Available at ARCO Alaska, Inc., P.O. Box 100360, Anchorage, Alaska 99510, U.S.A. 10 p.

WYANT, J.G., and KNAPP, C.M. 1992. Alaska North Slope oil-field restoration research strategy. ReportEPA/600/R-92/022. Corvallis, Oregon: U.S. Environmental Protection Agency.
YOUNKIN, W.E., and MARTENS, H.E. 1987. Long-term success of seeded species and their influence on native species invasion at abandoned rig site A-01, Caribou Hills, N.W.T., Canada. Arctic and Alpine Research 19:566-571. 